\title{
Booms and busts in commodity markets: bubbles or fundamentals?
}

Article

Accepted Version

Brooks, C., Prokopczuk, M. and Wu, Y. (2015) Booms and busts in commodity markets: bubbles or fundamentals? Journal of Futures Markets, 35 (10). pp. 916-938. ISSN 10969934 doi: https://doi.org/10.1002/fut.21721 Available at https://centaur.reading.ac.uk/39235/

It is advisable to refer to the publisher's version if you intend to cite from the work. See Guidance on citing.

To link to this article DOI: http://dx.doi.org/10.1002/fut.21721

Publisher: Wiley

All outputs in CentAUR are protected by Intellectual Property Rights law, including copyright law. Copyright and IPR is retained by the creators or other copyright holders. Terms and conditions for use of this material are defined in the End User Agreement.

\section{www.reading.ac.uk/centaur}

\section{CentAUR}

Central Archive at the University of Reading

Reading's research outputs online 


\title{
Booms and Busts in Commodity Markets: Bubbles or Fundamentals?
}

\author{
Chris Brooks, Marcel Prokopczuk and Yingying Wu *
}

February 4, 2015

\begin{abstract}
This paper considers whether there were periodically collapsing rational speculative bubbles in commodity prices over a forty year period from the late 1960s. We apply a switching regression approach to a broad range of commodities using two different measures of fundamental values - estimated from convenience yields and from a set of macroeconomic factors believed to affect commodity demand. We find reliable evidence for bubbles only among crude oil and feeder cattle, showing the popular belief that the extreme price movements observed in commodity markets were caused by pure speculation to be unsustainable.
\end{abstract}

JEL classifications: C12; G13; G14; G23; Q14; Q48

Keywords: Commodity futures; Speculative bubble; Switching regression; Convenience yield; Macroeconomic factors

\footnotetext{
${ }^{*}$ We thank Ogonna Nneji, Jonathan Wallen and participants at the International Conference on Futures and other Derivative Markets, Shanghai, 2014, for helpful comments. Brooks is at the ICMA Centre, University of Reading, UK. Prokopczuk is at Leibniz University Hannover, Germany. Corresponding author: Yingying Wu, International Business School Suzhou (IBSS) at Xi'an JiaotongLiverpool University, No 111 Ren'ai Rd., Suzhou Dushu Lake Higher Education Town, Suzhou Industrial Park, Jiangsu Province,PR China 215123. e-mail: yingying.wu@xjtlu.edu.cn. Telephone: +86 (0)512 81884826 .
} 


\section{Introduction}

The prices of many commodities experienced a spectacular run up during the period leading into the recent financial crisis. Gold prices, for example, rose by c.500\% between 2000 and 2011 before losing a third of their value by 2013. Standard economic theory suggests that changes in price levels will be governed by the laws of supply and demand, but it is unclear whether such extreme price swings over protracted periods can be justified fundamentally, leading to suggestions that they may arise from speculation.

Investors, of course, benefitted from the substantial rises in the prices of commodities in the early 2000s, and the trading profits made by those who bought early in the upswing drew in further waves of speculators. Commodities increasingly became regarded as an investable asset class in their own right, believed to have good diversification benefits, low correlations with stocks and bonds, and good hedging properties against inflation - a phenomenon which became known as the 'financialisation' of commodity markets. As a result, many new commodity index funds were established and their activities increased trading volumes and altered the balance of transactions between hedgers and speculators (see, for example, Irwin and Sanders (2012) and Masters (2008)). Several studies (Gilbert (2010); Tang and Xiong (2012) in particular) have noted the increases in correlations between the returns on different classes of commodities. They argue that this is the result of speculative activities rather than fundamental demand and supply factors that would be more likely to affect individual markets differentially. However, rice futures, for instance, are not included in investable commodity indices, and apples, which have no futures market, also experienced price surges at the same time as metals and energy (Irwin et al. (2009); Stoll and Whaley (2010)).

Since commodities are core inputs to the production process or are consumption goods, the roller coaster-like behavior of their prices has also been argued to have real consequences. In particular, there have been concerns that price spikes have adversely affected the social welfare of consumers, especially those in developing countries (see, e.g., Leyaro (2009)), since households there spend a relatively high proportion of their 
incomes on basic food and energy. Many commentators in the media explicitly laid the blame for the price rises and increased volatility squarely at the door of speculators, arguing that investment banks and funds were immoral to engage in strategies that may have pushed up food prices. ${ }^{1}$ While newspapers called for commodity speculation to be banned altogether, in a more measured response, governments and regulatory bodies have argued for it to be restricted, including a requirement for transparency in the reporting of speculative trades and the establishment of strict position limits. In 2006, a US Senate Permanent Subcommittee Staff Report claimed that traditional supply and demand forces could not fully explain the price increase that began from the beginning of $2000 .^{2}$ Later, the United Nations also blamed food price rises on trading in agricultural commodities rather than the actual food stocks in physical markets, arguing that "Over $\$ 400$ bn (of paper money) is traded - that's 20-30 times the physical production of the commodity", and calling for tighter regulation of investors to limit the formation of commodity bubbles. ${ }^{3}$

While it is undeniable that prices and volatilities rose quickly in a relatively short period of time during the early years of the new millennium, what is less clear is whether speculators were the cause or whether such price dynamics were caused by fundamental factors. The sprawling industrialisation of China and other parts of Southeast Asia and the consequent thirst of production processes for minerals, a more widespread use of cars throughout the world, and the switching of agricultural production to biofuels, have all been argued to have increased the basic demand for commodities, yet their supply is mostly inelastic in the short run and finite in the long run. This is likely to have led prices to rise, while increasing uncertainty about how fast demand would grow may have caused, or at least contributed to, increasing price volatility.

Reaching precisely the opposite conclusion to the studies above concerning the nega-

\footnotetext{
${ }^{1}$ In one particularly extreme example, Johann Hadri, writing in a blog for the Independent newspaper, argues that Goldman 'gambled on starvation' www.independent.co.uk/opinion/commentators/johann-hari/.

${ }^{2}$ http://www.gpo.gov/fdsys/pkg/CPRT-109SPRT28640/html/CPRT-109SPRT28640.htm

${ }^{3}$ The United Nations Conference on Trade and Development (UNCTAD) on No.25 Sep. 2012, accessed from http://unctad.org/en/PublicationsLibrary/presspb2012d1_en.pdf.
} 
tive impacts that commodity index traders were argued to have had on commodity price dynamics, Büyükşahin et al. (2010) find no significant change in the correlation between investable commodity and equity indices as trading activity increased; Büyükşahin et al. (2010) and Stoll and Whaley (2011) argue that commodity investment flows of index traders did not Granger-cause price fluctuations; and Hamilton (2009) did not discover an accumulation of inventory linked to prices. Similarly, Sanders et al. (2010) and Miffre and Brooks (2013) argue that long-short index arbitrageurs were not to blame either for rising volatility or for increases in correlations between the returns to commodities and other asset classes. Hence this strand of the literature argues in favour of the fundamental explanation for price spikes and increasing volatility in the early 2000s. Banks and hedge funds have, naturally, responded to popular criticism by arguing that, on the contrary, their activities have actually increased market depth, improved price discovery and that further regulation would be both unnecessary and counterproductive.

But would prices have risen and then collapsed anyway, irrespective of the activities of commodity index traders? While it is not possible to answer this counterfactual question with certainty, given the profound influence that policy interventions could exert, scholars have recently attempted to investigate the possible existence of speculative bubbles in commodity markets. It is clear that a formal evaluation of the possibility of bubbles in such series is warranted and yet there have been surprisingly few studies (discussed in detail below) that have done this. A speculative bubble is argued to exist if there are systematic, persistent and increasing deviations of actual prices from their fundamentally justifiable values. ${ }^{4}$ Among existing empirical studies, there is no clear conclusion that can be drawn so far as to whether commodity price series have been characterised by speculative bubbles or not. As Michael V. Dunn aptly put it in his 2011 opening statement to the US Commodity Futures Trading Commission (CFTC),

\footnotetext{
${ }^{4} \mathrm{~A}$ good early definition of a rational bubble is given by Diba and Grossman (1988): "A rational bubble reflects a self-confirming belief that an asset's price depends on a variable (or a combination of variables) that is intrinsically irrelevant - that is, no part of market fundamentals - or on truly relevant variables in a way that involves parameters that are not part of market fundamentals."
} 
"no one has presented to this agency any reliable economic analysis to support either the contention that excessive speculation is affecting the markets we regulate or that position limits will prevent excessive speculation."

We extend this emergent literature that investigates putative speculative bubbles in commodity markets in several important ways. First, we employ a much longer run of data than existing studies - our sample spans over forty years going back to the late 1960s. We would argue that it is not possible to robustly test for speculative bubbles in series that do not cover more than one price cycle. Second, we employ a much broader range of commodities than the one or two individual series used in the majority of existing studies. Such a comparative approach will enable us to much better tackle the issue of whether commodity markets have become financialised since if this is the case we might see bubbles in many commodity markets even where their underlying demand has risen less strongly. Third, and perhaps most importantly, unlike equity and real estate markets where the appropriate type of cashflow used to construct the fundamental measure is clear (dividends and rental income respectively), for commodities it is not immediately obvious how we should analogously construct the fundamental price. $^{5}$ Existing studies have employed convenience yield in this vein, but this series may itself be contaminated with a bubble since its estimation is based on the actual price. Therefore, we follow a second approach and obtain the fundamental value by exploiting the relationship of commodity prices with a set of macroeconomic factors that are widely believed to capture commodity demand. Finally, we employ a direct test for bubble presence based on a regime-switching specification, which, by actually specifying a model for the dynamics of the bubble and the underlying price series, provides more diagnostic information than the indirect technique based on recursive unit root tests employed in most extant research in the commodities arena.

Over the broad range of commodities we examine using the two measures of fun-

\footnotetext{
${ }^{5}$ In essence, the approach in the literature is to define fundamentals and then presume that any deviation from this represents speculation. As such, if the fundamentals are mis-specified, action from the actual prices will appear in the residuals and be mis-classified as speculation. As we demonstrate below, since our key finding is that there is little evidence for speculative bubbles, we need not be concerned about our results being driven by this issue.
} 
damental values, we find similar results in that only two commodities - feeder cattle and crude oil - are characterized by periodically collapsing speculative bubbles. Importantly, we can also infer that, for other markets not exhibiting evidence in favour of speculative bubbles, the high volatilities and price spikes must be attributed to other factors - for example, surging demand or supply interruptions.

The remainder of this paper is organized as follows: Section 2 presents the very limited extant evidence on the existence of bubbles in commodities. This section also explores the methods we use for deriving bubble fundamentals. Section 3 then outlines the empirical approach we adopt for bubble testing. Section 4 describes the data and variable construction while Section 5 discusses the empirical results. Section 6 concludes.

\section{Existing Evidence on Bubbles in Commodity Mar- kets}

Existing bubble tests can be classified into indirect and direct forms. The latter were proposed to exploit the theoretical characteristics of bubble processes in order to specify the dynamics of the bubble's development and the consequent implications for the movements of prices. To detect periodically collapsing bubbles, regime switching tests have been constructed by van Norden and Schaller (1993) where the probability of the bubble surviving is a function of its size, an approach used in numerous studies of bubbles in equity markets.

Compared to the large number of studies on stocks (and real estate), fewer investigations have been carried out in the context of commodities. However, the volatility of commodity prices has driven recent interest and a substantial amount of literature is now emerging, although the results thus far are still inconclusive. From a theoretical perspective, Hamilton (2009) shows how the price rises in 2007-08 arose as a result of growing world demand at times of limited supply growth, whereas previous price 
spikes had arisen predominantly from supply interruptions. These market conditions, combined with extremely low price elasticity of demand caused bubble-like price growth and then collapse when more standard levels of demand and supply resumed. Singleton (2014) develops a model where 'information frictions' combined with speculative activity leads to price inflation and subsequent collapse. The unwinding of similar positions by large institutions concurrently can cause bubble collapses, especially in illiquid markets Brunnermeier (2009).

One strand of the literature attributes the observed price spikes to fundamental variation mainly driven by local commodity activity - see, for example, Sanders and Irwin (2010), who did not find a uniform influence of new demand from index funds across different markets after applying a cross-sectional test. On the other hand, Robles et al. (2009) demonstrate the influential role of speculative activities. Using a widely employed bubble testing tool - the Johansen test - Liu and Tang (2010) find evidence of cointegration between prices and fundamentals for four commodity markets before 2004 but not after that, implying that the rise in commodity prices occurring during the mid- to late-2000s is mainly due to a rise in speculative activities, i.e. a bubble.

De Meo (2013) conducts various indirect bubble tests, including a variance bounds approach and a test on restrictions in a vector autoregressive model for crude oil and three non-ferrous metal commodity markets. It is argued, following a rolling window analysis, that commodity-specific factors rather than index investment trigger regime shifts. Similarly, Bialkowski et al. (2011) do not find supportive evidence for a speculative bubble in the gold market when applying a Markov regime-switching augmented Dickey-Fuller test to the residual of the gold price regressed on convenience yield. Other related bubble testing studies employing the Phillips and Yu (2011) recursive Augmented Dickey-Fuller test include Figuerola-Ferretti et al. (2012), who find mixed results from five metal and energy markets, Gutierrez (2013), who is able to identify collapsing bubbles for wheat, corn and rough rice but not for the soybean market and Etienne et al. (2013), who argue that the 12 agricultural markets they examine exhibit 
price explosiveness. Finally, Emekter et al. (2012) adopt a duration dependence test and some evidence for speculative bubbles is observed in 11 of 28 commodity markets under consideration.

More closely related to our study, a handful of papers testing for speculative bubbles in commodities use direct approaches. Among these, Liu et al. (2013) apply the regimeswitching regression model of van Norden and Schaller (1993) to wheat futures but the estimation results do not entirely accord with a periodically surviving and collapsing pattern. They note, however, that it may be that the convenience yield provides a poor representation of the fundamental value (most notably its lower explanatory power after 2004 - see also Liu and Tang (2010)). As we discuss in more detail below, empirical tests for a bubble are actually joint tests of the no bubble hypothesis and of having the correct model for the fundamental value.

Shi and Arora (2012) compare various three-regime switching models for the crude oil market and find supportive evidence for the widely claimed recent bubble in oil prices. Bertus and Stanhouse (2001) apply dynamic factor analysis to the gold market using the Kalman filter; no significant evidence for bubbles is found at conventional levels. Lammerding et al. (2013) treat the bubble component as state variable and find significant evidence for the existence of speculative bubbles in the oil market. Altogether, we might conclude that the existing evidence on speculative bubbles in commodity markets is sparse, limited in scope and yielding mixed results.

\subsection{Fundamental Values for Commodities}

We mentioned above that tests for speculative bubbles depend critically on the construction of appropriate fundamental values. As noted by Flood and Garber (1980), any omitted variable or measurement errors in the fundamentals can bias the bubble test in favour of rejection of the no-bubble null hypothesis. In the context of equities, dividends are the obvious choice of fundamental measure since they represent the ultimate cashflow received by investors; this role can similarly be fulfilled by rents in real 
estate applications. However, in the context of commodities, it is not entirely clear upon what basis fundamentals should be constructed since there exists no direct analogy to dividends and rents as commodity holders do not receive periodic monetary cashflows. Evidently, commodities have a final demand for use in production or consumption, and the implicit value from holding the spot commodity is captured by the convenience yield. ${ }^{6}$ Thus fundamental prices may be constructed from convenience yields, which then take the place of dividends in a discounted cashflow framework.

Alternatively, a proxy for the fundamental value may be obtained by relating the actual price of the commodity to a basket of variables that are thought to affect the forces of demand and/or supply. Accounting for plausible explanations of 2008 price peaks in commodities, namely easy monetary policy and strong economic growth, Frankel and Rose (2010) argue that commodity prices have both macroeconomic and microeconomic determinants. In their empirical testing results, all explanatory variables - both macroeconomic (the real interest rate, global GDP and the inflation rate) and microeconomic (inventories, the basis, and a measure of uncertainty) - variables show some effects on real commodity prices, although microeconomic factors have stronger and more consistent impacts. Similarly, in a study of the excess-comovement of commodity prices, Ai et al. (2006) demonstrate the high predictive power of macro-indicators and commodity-specific variables in explaining the price behavior of five agricultural commodities. $^{7}$

In the existing literature that tests for bubbles in commodities, the majority of studies (Liu and Tang (2010), De Meo (2013), Liu et al. (2013), Shi and Arora (2012), etc.) employ the present value model illustrated by Pindyck (1993) following Campbell and Shiller (1987) in using the marginal convenience yield. Pindyck argues that changes

\footnotetext{
${ }^{6}$ Brennan (1958) defines convenience yield as the benefit from holding the underlying to the physical holder as it can smooth production shortages and meet unexpected demand from the product market.

${ }^{7}$ In our study, we employ US-based macroeconomic series despite the fact that commodity markets are global. We believe that this apparent mis-match is not consequential since Geman and Ohana (2009) show that for the case of crude oil, it does not matter whether US or global inventories are used as the world economy is highly correlated with that of the US. In addition, using US based data circumvents numerous potential aggregation issues relating to differences in currencies and units of measurement.
} 
in the demand for and supply of commodities cause changes in current and expected convenience yields and thus the present value model is considered a parsimonious form of a dynamic equilibrium model. The empirical evidence from four commodities show different levels of conformity with the model. For heating oil, with the lowest level of serial correlation, the model fits the best. On the other hand, the model does not provide a good characterization for gold, where high serial correlation is found in excess returns. The mixed results may indicate the limits of the model set up or provide evidence that the prices of some commodities may be driven by 'fads' or other nonfundamental factors. It is also possible that the strong conformity in the case of heating oil together with low serial correlation in its excess returns may be caused by the high levels of convenience yield for that series, which makes speculation more costly. ${ }^{8}$

\section{Economic Modeling and Empirical Investigation}

\subsection{Rational Asset Pricing}

The present value model depicts the fundamental value of an asset as the sum of the current and the discounted future cashflows from its ownership. Under rational expectations and assuming a constant discount rate, a risk-neutral investor requires that the risky asset price is given by:

$$
P_{t}=(1+r)^{-1} E_{t}\left(P_{t+1}+Y_{t}\right)
$$

where $P_{t}$ is the actual price of the asset at time $t, r$ is the discount rate, $Y_{t}$ is the endowment received (e.g., dividends for stocks and convenience yields for commodities), and $E_{t}$ denotes the expectation conditional on information at time $t$. In a multi-period

\footnotetext{
${ }^{8} \mathrm{~A}$ further approach to measuring fundamentals is due to Bertus and Stanhouse (2001), who build an equilibrium model where market participants' utilities are maximized; however, their approach is less than intuitive and has consequently not been the subject of any additional applications.
} 
framework, looking $T$ periods forward we obtain:

$$
P_{t}=\sum_{k=0}^{T}(1+r)^{-(k+1)} E_{t}\left(Y_{t+k}\right)+(1+r)^{-T} E_{t}\left(P_{t+T}\right)
$$

The second term on the right-hand side converges to zero at an infinite horizon when the transversality condition is met, and thus if the expected growth rate of the asset price does not surpass $r$, then Equation (2) collapses to the familiar 'discounted dividend' model in the context of an application to stocks: ${ }^{9}$

$$
P_{t}=\sum_{k=0}^{\infty}(1+r)^{-(k+1)} E_{t}\left(Y_{t+k}\right)
$$

If the transversality condition fails, apart from the result in (3), an alternative solution to (1) is where $P_{t}$ contains a bubble. In such circumstances, the price constructed from $(3)$ is the fundamental price, $P_{t}^{*}$, rather than the actual price, $P_{t}$. The bubble component, $B_{t}$, systematically drives the market price away from this fundamental price:

$$
P_{t}=P_{t}^{*}+B_{t}
$$

The bubble term can follow different evolutionary processes depending on the forces driving it. Nevertheless, even when the asset price contains a bubble, Equation (1) should still hold so that there are no arbitrage opportunities. Hence the bubble must follow:

$$
E_{t}\left(B_{t+1}\right)=(1+r) B_{t}
$$

Thus the bubble is expected to grow at the required rate of return and hence the continuing existence of the bubble is rational. Investors hold the asset with the expectation of a capital gain even when market prices are already above fundamental values since it is only possible to predict probabilistically when the bubble will collapse - see O'Hara (2008).

\footnotetext{
${ }^{9}$ In fact, Equation (3) will also apply when $Y_{t}$ is based on other types of cashflows, such as rents or those arising implicitly from the convenience yield.
} 


\subsection{Commodity Fundamental Value}

As discussed above, there is no consensus on commodity fundamental valuation, and hence we achieve this by separately employing two methods at the first step of the empirical investigation and we compare the resulting bubble models.

Method 1: Although the benefit to the physical holders of commodities (the convenience yield) does not come in the form of a cashflow as for other assets such as equities in terms of the dividend, the basic present value model should apply equally to commodities as it does to any asset which yields actual payoffs, as argued by Pindyck (1993). This provides the foundation for our first approach to fundamental valuation. The accrued convenience yield from holding storable commodities can provide a highly reduced model of commodity markets, where changes in demand from and supply to the market are integrated into changes in current and expected future convenience yields.

Similar to the approach by van Norden and Schaller (1993) in the context of stocks paying dividends and by Liu and Tang (2010) on the commodity price with convenience yields, we regress observed futures prices on net convenience yields, and the residuals, $\hat{\varepsilon}_{1, t}$, are taken as deviations from fundamental values: ${ }^{10}$

$$
P_{t}=\lambda_{1,0}+\lambda_{1,1} \delta_{t}+\varepsilon_{1, t}
$$

where $\delta_{t}$ stands for the net convenience yield at time $t$. It is worth mentioning that we test for bubbles in real terms, and thus all nominal futures price series are deflated with a general price index.

Unfortunately, the series of convenience yields in Equation (6) is not observable, and we thus need to extract it from futures market data. In the framework of the theory of storage, the price of the futures contract $F_{t, T}$ maturing at $T$ and observed at $t$ can be

\footnotetext{
${ }^{10}$ It is common in the literature e.g., in Fama and French (1987), that the spot price of commodities is proxied by the most nearby futures contract, not only due to the higher liquidity in the futures market than the relatively rarely traded spot market, but also because the use of the futures contract for the spot price ensures that the same underlying is adopted for both spot and futures prices.
} 
linked with the spot price $\left(P_{t}\right)$ as follows:

$$
F_{t, T}=P_{t}\left(1+\left(r_{t}^{f}-\delta_{t}\right)\left(\frac{T-t}{252}\right)\right)
$$

with $r_{t}^{f}$ denoting the annual risk-free rate from time $t$ to $T .{ }^{11}$ For simplicity, both risk-free rate and convenience yield are assumed constant over the period from $t$ to $T$. Rearranging Equation (7), annualized net convenience yield observations can effectively be extracted as:

$$
\delta_{t}=r_{t}^{f}+\left(1-\frac{F_{t, T}}{P_{t}}\right) \frac{252}{T-t}
$$

It is important to note, however, that such an application of the present value model faces several issues regarding the use of convenience yields. First, the convenience yield is latent. For commodities traded in the futures market, only the convenience yield net of the storage costs can be estimated, within which the variation in storage cost cannot be stripped away. Second, the maturity of the convenience yield may vary over time. Not all commodities have futures contracts traded at regular intervals, and thus the maturities of the convenience yields from the two most nearby futures contracts are not necessarily consistent at different points in time. Third, the convenience yield could be contaminated with a bubble since it is estimated based on the actual spot price itself. This makes it difficult to disentangle the fundamental and bubbly parts of the price series based on convenience yields. Thus, we employ a second approach for estimating the fundamental value.

Method 2: Given the limitations of convenience yields as a fundamental measure, for comparison we make use of economic factors which have been empirically validated as influencing the demand for and/or the supply of commodities. A similar approach can be found in tests for bubbles in other asset classes but we are the first to use it in the context of commodities. For example, Roche (2001) investigates the rise in house prices in Dublin, where fundamental values are based on the inverted demand

\footnotetext{
${ }^{11}$ Note that the convenience yield extracted here is the net value with regard to storage, handling and insurance costs, etc.
} 
function of expected disposable incomes, expected real mortgage rates and so on. In Method 2, we therefore regress commodity prices against a set of economic variables. The residuals, $\hat{\varepsilon}_{2, t}$, from the estimation are taken as the bubble term $B_{t}$.

A well-known characteristic of some commodities, especially those in the grain, animal and energy classes, is the seasonality in their price series due to harvest and/or consumer behavior patterns - see, e.g., Fama and French (1987). ${ }^{12}$ Most fundamental economic series used in our study are obtained after seasonal adjustment and we also include seasonal dummy variables in the regression equation as:

$$
P_{t}=\sum_{j=1}^{12} \gamma_{2, j} D_{t, j}+\sum_{i=1}^{4} \lambda_{2, i} X_{t, i}+\varepsilon_{2, t}
$$

where $D_{t, j}$ are monthly dummy variables employed to capture the seasonality. With the guidance of Frankel and Rose (2010), the factors included in $X_{t, i}$ of the regression model for the fundamental values are: (1) industrial production, which measures how the general level of the economy affects the demand for commodity markets that include many raw materials playing a vital role in production processes; (2) housing starts, which serves as complementary proxy for general economic activity and is believed to be a leading economic indicator; (3) real personal consumption expenditure, which takes into account the demand variation from consumer purchasing power and is especially relevant for the agricultural and soft sectors; (4) three-month treasury bill yields, which captures monetary policy effects on commodity markets. ${ }^{13}$

\footnotetext{
${ }^{12}$ For the convenience yield regressions (Equation (6)), the seasonal dummy variables are not necessary since the independent variables (the convenience yields) also themselves show seasonality - see, e.g., Brooks et al. (2013), and so these could account for the seasonality in the dependent variable (commodity prices) if it exists.

${ }^{13}$ Due to data availability, we have to drop two of the variables used by Frankel and Rose (2010) in the main part of this study to maximise the number of observations available: the US dollar index, which affects the overseas demand for commodities and also inventory levels, which play a role in the supply of commodities. The available inventory data also have several issues - see e.g. Gorton et al. (2013) regarding the different data sources across commodities, lag of announcements, short history available, etc. Compared to their demand, the supply of commodities is more inelastic, and thus we focus on factors that affect the demand function in determining our fundamental values.
} 


\subsection{Speculative Bubbles and Estimation}

The two-regime switching regression model introduced by van Norden and Schaller (1993) (vNS hereafter) is employed as the main tool of analysis. In the two-regime model, the bubble $\left(B_{t}\right)$ evolves between a surviving regime $(S)$ and a collapsing regime $(C) .{ }^{14}$ Although there exists an extended three-regime switching regression (see Brooks and Katsaris (2005)) where the model is augmented to include a third (dormant) regime in which the bubble grows at the fundamental rate of return in addition to the collapsing and surviving regimes, we adopt the statistically more parsimonious and stable two-regime model mainly due to the limited number of observations available for commodities compared with equities.

Based on the earlier model of Blanchard and Watson (1983), the approach by vNS adopts a more general specification that overcomes important limitations of the previous generation of rational bubble specifications. First, the collapsing probability is not constant but a function of the relative (to the actual price) bubble size. Second, the expected value of the bubble conditional on collapse is non-zero, allowing for partial collapsing, which falls in line with some common features of historical crash periods. In detail, considering that the probability of a crash increases with the speculative component in the price, vNS assume $q$, the probability of survival, to be a decreasing function of the relative size of the speculative component $\left(b_{t}\right)$ :

$$
\begin{gathered}
q \equiv q\left(b_{t}\right) \\
\frac{\mathrm{d} q\left(b_{t}\right)}{\mathrm{d}\left|b_{t}\right|}<0
\end{gathered}
$$

where $b_{t} \equiv B_{t} / P_{t}$, the relative size of the bubble, is the ratio of the bubble size $\left(B_{t}\right)$ to the actual commodity spot price $\left(P_{t}\right)$, and $\left|b_{t}\right|$ is the absolute value of $b_{t}$, implying that the bubble can be either positive or negative in this model.

\footnotetext{
${ }^{14}$ As Schaller and van Norden (2002) point out, the switching-regression model here has one state independent probability, which is a special case of a Markov-switching model since today's state is independent of yesterday's.
} 
To account for the fact that the bubble term may not collapse in one single period, i.e. partial collapsing, they specify the expected value of $B_{t+1}$ conditional on collapse to be a function $u$ of $b_{t}$ :

$$
E\left(B_{t+1} \mid C\right)=u\left(b_{t}\right) P_{t} \quad \text { with probability } q\left(b_{t}\right)
$$

where $u($.$) is a continuous and everywhere differentiable function such that u(0)=0$ and $0 \leq \frac{\mathrm{d} u\left(b_{t}\right)}{\mathrm{d} b_{t}}$. This condition ensures that the bubble is expected to shrink in the collapsing state. Combining Equations (12), (10) and (5), we have the expected value of the bubble term conditional on being in the surviving state:

$$
E\left(B_{t+1} \mid S\right)=\frac{1+r_{t}}{q\left(b_{t}\right)} B_{t}-\frac{1-q\left(b_{t}\right)}{q\left(b_{t}\right)} u\left(b_{t}\right) P_{t} \quad \text { with probability } \quad 1-q\left(b_{t}\right)
$$

It is worthwhile pointing out that the restrictions on $u\left(b_{t}\right)$ and $q\left(b_{t}\right)$ are not imposed on the data but rather are designed to test whether speculative bubbles are a possible explanation for the dynamic behavior of prices. We can convert the above equations into switching regressions for expected excess returns in each regime as a function of the bubble size:

$$
\begin{aligned}
E_{t}\left(R_{t+1} \mid S\right) & =\frac{1-q\left(b_{t}\right)}{q\left(b_{t}\right)}\left[\left(1+r_{t}\right) b_{t}-u_{t}\left(b_{t}\right)\right] \\
E_{t}\left(R_{t+1} \mid C\right) & =u\left(b_{t}\right)-\left(1+r_{t}\right) b_{t}
\end{aligned}
$$

where $E_{t}\left(R_{t+1} \mid S\right),\left(E_{t}\left(R_{t+1} \mid C\right)\right)$, denote the expected excess return from time $t$ to $t+1$ conditional on survival (respectively, collapse), dependent on all information available at the end of period $t$.

After taking the first-order Taylor expansion of Equation (14) around an arbitrary 
value $b_{0}$, we have the linearized equations:

$$
\begin{aligned}
& E_{t}\left(R_{t+1} \mid S\right)=\beta_{S 0}+\beta_{S 1} b_{t} \\
& E_{t}\left(R_{t+1} \mid C\right)=\beta_{C 0}+\beta_{C 1} b_{t}
\end{aligned}
$$

with

$$
\begin{aligned}
\beta_{S 1} & \equiv\left(-\frac{1}{q\left(b_{0}\right)^{2}} \frac{\mathrm{d} q\left(b_{0}\right)}{\mathrm{d} b_{t}}\left[\left(1+r_{t}\right) b_{0}-u\left(b_{0}\right)\right]+\frac{1-q\left(b_{0}\right)}{q\left(b_{0}\right)}\left[1+r_{t}-\frac{\mathrm{d} u\left(b_{0}\right)}{\mathrm{d} b_{t}}\right]\right) \\
\beta_{C 1} & \equiv\left[\frac{\mathrm{d} u\left(b_{0}\right)}{\mathrm{d} b_{t}}-\left(1+r_{t}\right)\right]
\end{aligned}
$$

Given that $r_{t}>0,0 \leq \frac{\mathrm{d} u\left(b_{t}\right)}{\mathrm{d} b_{t}} \leq 1$ and $\frac{\mathrm{d} q\left(b_{t}\right)}{\mathrm{d}\left|b_{t}\right|}<0$, it is easy to show that $\beta_{S 1} \geq$ 0 and $\beta_{C 1} \leq 0$, or more generally, $\beta_{C 1}<\beta_{S 1}$. This implies that in the surviving regime, the expected return is positively related to the size of the bubble and in the collapsing regime the expected return and bubble size are negatively correlated. Moreover, to ensure that the probability $q(t)$ is within the range between 0 and 1 , following vNS, we adopt a probit functional form for the probability of the bubble surviving in period $t+1$ :

$$
q_{t+1}=\Phi\left(\beta_{q 0}+\beta_{q 1}\left|b_{t}\right|\right)
$$

where $\Phi$ is the standard normal cumulative density function. As we assume $\frac{\mathrm{d} q\left(b_{t}\right)}{\mathrm{d}\left|b_{t}\right|}<0$, if $\beta_{q 1}<0$, the probability of staying in the surviving regime is a decreasing function of the bubble size.

By substituting the realized values for the expected returns in Equation (15) and adding an error term, together with Equation (16), the switching-regression equation can be written as:

$$
\begin{aligned}
R_{t+1} \mid S & =\beta_{S 0}+\beta_{S 1} b_{t}+\epsilon_{t+1} \mid S \\
R_{t+1} \mid C & =\beta_{C 0}+\beta_{C 1} b_{t}+\epsilon_{t+1} \mid C \\
q_{t+1} & =\Phi\left(\beta_{q 0}+\beta_{q 1}\left|b_{t}\right|\right)
\end{aligned}
$$


where $\epsilon_{t+1} \mid i \sim N\left(0, \sigma_{i}\right),(i=S, C)$ and $\sigma_{S}, \sigma_{C}$ denote the standard deviations of the unexpected excess returns $\left(\epsilon_{t+1}\left|S, \epsilon_{t+1}\right| C\right)$ in the two regimes. Thus, the switchingregression model can be estimated by maximising the log-likelihood function $(L L)$ :

$$
\begin{aligned}
L L= & \sum_{t=1}^{N} \ln \left\{q_{t+1} \varphi\left(\frac{R_{t+1} \mid S-\beta_{S 0}-\beta_{S 1} b_{t}}{\sigma_{S}}\right) \sigma_{S}^{-1}\right. \\
& \left.+\left(1-q_{t+1}\right) \varphi\left(\frac{R_{t+1} \mid C-\beta_{C 0}-\beta_{C 1} b_{t}}{\sigma_{C}}\right) \sigma_{C}^{-1}\right\}
\end{aligned}
$$

where $\varphi$ is the standard normal density function. The parameters of the regressions and the optimal regime for each observation do not need to be assumed beforehand but are estimated together with the probability of being in regime $i=S, C$ at time $t+1$ dependent on the size of $b_{t}$ as shown in Equation (16).

Summarizing, to test whether the speculative bubble can explain the observed behavior of commodity prices, Equations (17) are estimated and the following constraints on the parameters must hold: ${ }^{15}$ (i) $\beta_{C 0} \neq \beta_{S 0}$ implies that the mean returns are different between the two regimes; (ii) $\beta_{C 1} \leq 0$ ensures that the expected return is a negative function of the bubble in the collapsing regime; (iii) $\beta_{C 1}<\beta_{S 1}$ implies that the bubble yield is higher in the surviving regime than in the collapsing regime when the bubble is positive; (iv) $\beta_{q 1}<0$ must hold for the probability of surviving to decrease with increasing bubble size. If these constraints are met and the variation in futures returns can be captured by the model, then it gives credibility to arguments in favor of the existence of periodically collapsing bubbles.

\section{Data Sources and Variable Construction}

\subsection{Commodity Futures and Excess Returns}

In total, we consider 18 commodities in our study which can be categorized into five subgroups, namely: grains, softs, animals and woods, precious metals, and energy.

\footnotetext{
${ }^{15}$ Likelihood ratio tests are employed to test these restrictions in the empirical analysis.
} 
Futures prices are sampled on the first working day of each month from February 1967 to December 2011, although for some commodities, e.g. coffee and feeder cattle, the sampling dates are different due to data availability. The details of the sample period for each series together with information regarding commodity names and exchanges are listed in Panel A of Table 1. This period of over forty years spans several market booms and falls, importantly covering the two episodes that peaked in 1974 and 2008, the commodities depression in the 1990s, and also the credit crunch and sovereign debt crisis in the 2000s. Although commodity futures prices are available on a daily basis, we use monthly data mainly because we want to disentangle the bubbly aspects of behavior from the variations caused by microstructure mechanisms in the market that affect higher frequency data. More importantly, most of the influential factors that we wish to incorporate into the fundamental model (e.g., macroeconomic factors) are available on a monthly basis only.

Commodity futures prices are obtained from the database maintained by the Commodity Research Bureau (CRB). In Table 1, Panel B presents summary statistics of the most nearby commodity futures price series in real terms. Although the units differ across commodities, comparing the standard deviations to the mean values of the most nearby futures prices, we find that some commodities such as coffee, cocoa and silver are more volatile while feeder cattle and lumber are much less so.

The annualized monthly total excess logarithmic return, $R_{t}$, for each individual commodity (the dependent variable of Equation (17)), is computed by rolling the long position in the most nearby futures contract $F_{t, T}$ (as a proxy for the spot price, $P_{t}$ ) at time $t-1$ and $t$ :

$$
R_{t}=\left(\ln F_{t, T}-\ln F_{t-1, T}\right) \frac{252}{n}+\delta_{t}-r_{t}^{f}
$$

where $n$ denotes the number of business days between $t-1$ and $t$. Taking into account that the most nearby futures may roll over across two different contracts between time $t-1$ and $t$, we compose the monthly return of two parts if the contract changes during that period. So if the most nearby contract is rolled over from $F_{t^{*}, T_{1}}$ to $F_{t^{*}, T_{2}}$ at time 
$t^{*}\left(t-1 \leq t^{*} \leq t\right)$, the annualized monthly return $R_{t}$ can be written:

$$
R_{t}=\left[\left(\ln F_{t^{*}, T_{1}}-\ln F_{t-1, T_{1}}\right)+\left(\ln F_{t, T_{2}}-\ln F_{t^{*}, T_{2}}\right)\right] \frac{252}{n}+\delta_{t}-r_{t}^{f}
$$

Summary statistics of the individual total excess returns are presented in Panel $\mathrm{C}$ of Table 1.13 of 18 commodities have negative average monthly returns in real terms from holding the most nearby futures contracts, which implies contango is typical for these commodities. We can infer that the remaining commodities generally show backwardation over the sample period. In particular, the result for crude oil is in line with the backwardation observed in previous studies - see, for example Litzenberger and Rabinowitz (1995). Energy commodities are the most highly volatile and feeder cattle the least. The natural gas returns series in particular has double the monthly standard deviation compared with most of the other series. All returns series except four are positively skewed and have a coefficient of kurtosis greater than three. These findings confirm the well known characteristics of commodities returns compared with equity returns, which are also leptokurtic but negatively skewed.

\subsection{Macroeconomic Factors}

The following aggregate variables are used for the regression-based fundamental valuations on a monthly basis and are obtained from the Federal Reserve Economic Database (FRED) of the Federal Reserve Bank of St. Louis:

Industrial Production (Final Products) (seasonally adjusted) - gauges real output for all facilities located in the US (excluding those in US territories).

Housing Starts (Total: New Privately Owned Housing Units Started) (seasonally adjusted) - captures the number of privately owned new houses on which construction has been started in a given period.

Real Personal Consumption Expenditures (seasonally adjusted) - reflects the actual and imputed expenditures of households and is a measure of the value of goods and services consumed by individuals. 
3-Month Treasury Bill Yield (Secondary Market Rate) - is the discount yield of 3M T-Bills in the secondary market.

To deflate the commodity price series we also obtain the Consumer Price Index for All Urban Consumers (seasonally adjusted), which is representative of the buying habits of approximately 80 percent of the non-institutional population of the US.

\section{Empirical Results}

\subsection{Bubble Measures}

From Equations (6) and (9), we have the deviations from fundamentals, $\hat{\varepsilon}_{t}$, which we treat as the bubble, $B_{t}$. It is important to note at this stage that strictly, these deviations from fundamentals may or may not be accurately described as bubbles; indeed, as we show below, most commodity series show little support for bubbles. However, we continue to use the term 'bubble' in place of 'non-fundamental' in the discussion below following the literature and for brevity. Descriptive statistics of the relative fundamental deviations are presented in Table 2. The maximum, minimum, average, standard deviation, skewness and kurtosis of $b_{t}$ based on convenience yields are shown in Panel A, while those based on macroeconomic variables are displayed in Panel B. We observe that the deviations from fundamentals can be either positive or negative, although on average they are below zero for both methods of constructing fundamentals, corresponding with the long bear market that persisted in commodities throughout the 1980s and most of the 1990s. Most of the bubble series have negative skewness except feeder cattle and platinum under the convenience yield approach, and soybean meal and gold under the macroeconomic fundamental model. In general, the convenience yield-based bubbles are more volatile and more skewed than those based on macroeconomic variables, although the former are almost invariably with thinner tails than the latter.

The fundamental values, $P_{t}^{*}$, of a subset of commodities are displayed in Figure 1 
together with real commodity spot prices, $P_{t} \cdot{ }^{16}$ One can observe that grain and soft commodities generally show positive price spikes around 1974, and relatively smaller ones from 2007, while precious metals and energy commodities only show discernable bubbles in the late 2000s. By visually comparing the bubbles using the two approaches to measuring fundamentals, we find that in general they follow similar, yet somewhat different, profiles over time.

\section{$5.2 \quad$ Switching-regression Results}

Table 3 provides the estimated coefficients of the two-regime switching regression using the bubble obtained based on the convenience yield constructed using the methods outlined in Subsection 3.2 above. We can observe that for almost all commodities the coefficients do not meet the requirements implied for the presence of periodically bursting bubbles to be plausible. There are only two exceptions to this among the 18 commodities considered: feeder cattle shows strong evidence for a bubble and crude oil exhibits some evidence. Specifically, for feeder cattle, $\beta_{C 1}$ and $\beta_{q 1}$ are significantly negative with $95 \%$ confidence, implying that both the return of the next period and the probability of staying in the survival regime are decreasing functions of the bubble component as required. Also, the return is expected to be higher in response to bubble growth in the surviving regime as implied by the significant positive $\beta_{S 1}$. The mean returns differ between the two regimes, with $\beta_{S 0}>\beta_{C 0}$, which intuitively implies higher expected returns in the surviving regime than in the collapsing regime. The average annualized excess returns are $14 \%$ and $-10 \%$ respectively in the surviving and collapsing regimes. The volatility of the error term in the surviving regime $\left(\sigma_{S}\right)$ is at a lower level than in the collapsing regime $\left(\sigma_{C}\right)$ with very high confidence. Moreover, the likelihood ratio tests of these restrictions presented in Table 4 lend some support to the notion of bubble existence in the feeder cattle market. First, three statistics are significant with at least $95 \%$ confidence and the fourth $p$-value of the likelihood statistic is 0.13 .

\footnotetext{
${ }^{16}$ Due to space constraints, only a subsample of commodities from each sector are displayed as exemplars.
} 
The average ex ante probability of being in the surviving regime at time $t$, defined by $\Phi\left(\beta_{q 0}\right)$, is $64.43 \%$, but it is not significant at conventional levels.

For crude oil, all four coefficients constraints are broadly met, and more than half model estimates as well as the likelihood ratio tests are significant at conventional levels. We also infer the ex ante probability of being in the surviving regime, $\Phi(2.04)$, to be 97.93\%. This result corroborates the findings of Shi and Arora (2012) and Lammerding et al. (2013) regarding this market.

Table 5 presents the model estimation results from the bubble derived based on macroeconomic variables. Although in general more commodities - e.g. corn, soybean oil, cocoa and gold - show either a significant negative $\beta_{C 1}$ or $\beta_{q 1}$ (or both), none of the other coefficient constraints can be met. For example, the mean excess return for soybean oil is lower in the surviving regime $(-13 \%)$ than in the collapsing regime $(52 \%)$, which is counterintuitive. Considering the coefficient estimates and the restrictions for valid bubble processes collectively, in addition to the two commodities feeder cattle and crude oil, wheat also demonstrates some evidence of periodically collapsing speculative bubbles. All the coefficient estimates in Table 5 together with the first three likelihood ratio tests in Table 6 are highly significant and of plausible magnitudes. However, the average ex ante probability of being in the surviving regime is implausibly low: $\Phi(-1.04)=14.9 \%$.

Thus, integrating the results from Tables 3 and 5 with the likelihood ratio test results in Tables 4 and 6, we can draw the conclusion that among all 18 commodities investigated, only feeder cattle and crude oil exhibit signs for periodically collapsing speculative bubbles. In all other markets, no convincing evidence for the existence of bubbles is found. This is our main result.

It is also of interest to investigate how well the estimated ex ante probabilities of the bubble collapsing (defined as one minus the probability of surviving) can capture real commodity price variations over time. Figures 2 and 3 plot these ex ante probabilities of collapsing based on the estimate results from using convenience yields 
and macroeconomic variables together with the spot prices for these two commodities (feeder cattle and crude oil respectively). Visually we observe that the probability of collapsing based on macroeconomic variables can capture the price drops more closely. For example, for feeder cattle there are several dates with the probability of collapsing above 50\% - around 1975, 1979, 1986 and 1996 - and all but the third of these dates are accompanied by clear price dives. The probability of collapsing for crude oil overall is lower than that for feeder cattle. Compared with the highest value of $99.07 \%$ in March 1975 for feeder cattle, the highest probability is $37.16 \%$ in March 2009 for the crude oil market. However, the spikes in probability also coincide with significant price falls and the figure gives further credence to the generally agreed crude oil crash in late 2008 see, e.g. Singleton (2014) and Phillips and Yu (2011). We should note, however, that while the macro-based fundamentals give a more accurate profile to the probabilities of collapse, the rises in the likelihoods of the bubble bursting occur at the same time as, or even slightly after, the actual price drops. This would evidently limit the usefulness of the model for market participants.

\subsection{Robustness Checks and Additional Analysis}

We conducted several robustness checks. First, we added inventory information as a determinant of supply dynamics in the fundamental valuation to the analysis. Our core results remained unchanged. Second, we augment the switching regime probability and the expected return with hedging pressure information. Again, our findings do not change. These analyses are not presented due to space constraints, but available on request.

\section{Conclusions}

In this study, we have tested a broad range of commodities for switching speculative behavior with over forty years of data from February 1967 to December 2011. In 
contrast with the existing literature in this area, we adopt two different methods to measure fundamental values. One draws on the present value model and employs convenience yields, while the other relies on macroeconomic variables that are generally agreed to affect commodity fundamental values. Despite the considerable differences in the theoretical foundations and data used for the two methods, we obtain similar and robust results that only two of the 18 commodities investigated (feeder cattle and crude oil) provide convincing evidence of periodically collapsing bubbles. The use of additional variables in the fundamental model and in the bubble specification do not alter our core results.

Our findings add to a growing body of evidence running counter to the broadly held popular belief that commodity index traders and other speculators caused the inception of widespread speculative bubbles that formed and collapsed over the past decade. We thus attribute the considerable price rises and subsequent falls that occurred over this period to fundamental factors that changed either current or future expected demand for commodities in production processes or as consumption goods and to temporary supply shocks. Therefore, from the perspective of speculative bubbles at least, additional regulation of the activities of investors is probably unnecessary and as Sanders and Irwin (2011) and Miffre and Brooks (2013) note, it could have adverse consequences for liquidity and market depth, and worse, may force speculators into the cash markets. 


\section{References}

Ai, C., Chatrath, A., and Song, F. (2006). On the comovement of commodity prices. American Journal of Agricultural Economics, 88(3):574-588.

Bertus, M. and Stanhouse, B. (2001). Rational speculative bubbles in the gold futures market: an application of dynamic factor analysis. Journal of Futures Markets, 21(1):79-108.

Bialkowski, J., Bohl, M., Stephan, P., and Wisniewski, T. (2011). Is there a speculative bubble in the price of gold? Working paper, SSRN.

Blanchard, O. J. and Watson, M. W. (1983). Bubbles, rational expectations and financial markets. Working paper, National Bureau of Economic Research.

Brennan, M. (1958). The theory of storage. American Economic Review, 48(1):50-72.

Brooks, C. and Katsaris, A. (2005). A three-regime model of speculative behaviour: Modelling the evolution of the S\&P 500 composite index. Economic Journal, 115(505):767-797.

Brooks, C., Prokopczuk, M., and Wu, Y. (2013). Commodity futures prices: More evidence on forecast power, risk premia and the theory of storage. Quarterly Review of Economics and Finance, 53(1):73-85.

Brunnermeier, M. (2009). Deciphering the liquidity and credit crunch 2007-2008. Journal of Economic Perspectives, 23:77-100.

Büyükşahin, B., Haigh, M. S., and Robe, M. A. (2010). Commodities and equities: Ever a market of one? Journal of Alternative Investments, 12(3):76-95.

Campbell, J. and Shiller, R. (1987). Cointegration and tests of present value models. Journal of Political Economy, 95(5):1062-1088.

De Meo, E. (2013). Are commodity prices driven by fundamentals? Economic Notes, 42(1):1946.

Diba, B. T. and Grossman, H. I. (1988). The theory of rational bubbles in stock prices. Economic Journal, 98(392):746-754.

Emekter, R., Jirasakuldech, B., and Went, P. (2012). Rational speculative bubbles and commodities markets: application of duration dependence test. Applied Financial Economics, 22(7):581-596. 
Etienne, X., Irwin, S., and Garcia, P. (2013). Bubbles in food commodity markets: Four decades of evidence. Journal of International Money and Finance, forthcoming.

Fama, E. and French, K. (1987). Commodity futures prices: Some evidence on forecast power, premiums, and the theory of storage. Journal of Business, 60(1):55-73.

Figuerola-Ferretti, I., Gilbert, C. L., and McCrorie, J. R. (2012). The recent behavior of commodity prices: fundamentals, speculative bubbles and relation to the global economic environment. Working Paper.

Flood, R. P. and Garber, P. M. (1980). Market fundamentals versus price-level bubbles: The first tests. Journal of Political Economy, 88(4):745-70.

Frankel, J. A. and Rose, A. K. (2010). Determinants of agricultural and mineral commodity prices. Working paper, John F. Kennedy School of Government, Harvard University.

Geman, H. and Ohana, S. (2009). Forward curves, scarcity and price volatility in oil and natural gas markets. Energy Economics, 31:576-585.

Gilbert, C. (2010). How to understand high food prices. Journal of Agricultural Economics, 61(2):398-425.

Gorton, G., Hayashi, F., and Rouwenhorst, K. (2013). The fundamentals of commodity futures returns. Review of Finance, 17(1):35-105.

Gutierrez, L. (2013). Speculative bubbles in agricultural commodity markets. European Review of Agricultural Economics, 40(2):217-238.

Hamilton, J. (2009). Causes and consequences of the oil shock of 2007-09. Brookings Papers on Economic Activity, 40:215-261.

Irwin, S. and Sanders, D. (2012). Financialization and structural change in commodity futures markets. Journal of Agricultural and Applied Economics, 44(3):371-396.

Irwin, S. H., Sanders, D. R., Merrin, R. P., et al. (2009). Devil or angel? The role of speculation in the recent commodity price boom (and bust). Journal of Agricultural and Applied Economics, 41(2):377-391. 
Lammerding, M., Stephan, P., Trede, M., and Wilfling, B. (2013). Speculative bubbles in recent oil price dynamics: Evidence from a Bayesian markov-switching state-space approach. Energy Economics, 36(C):491-502.

Leyaro, V. (2009). Commodity price changes and consumer welfare in tanzania in the 1990s and 2000s. In CSAE Conference-2009 Economic Development in Africa, St Catherine College, Oxford, www. csae. ox. ac. uk/conferences/2009-EDiA/papers/345-Leyaro. pdf.

Litzenberger, R. and Rabinowitz, N. (1995). Backwardation in oil futures markets: Theory and empirical evidence. Journal of Finance, 50(5):1517-45.

Liu, P. and Tang, K. (2010). Bubbles in the commodity asset class: Detection and sources! Working Paper, Center for Real Estate and Finance, Cornell University.

Liu, X., Filler, G., and Odening, M. (2013). Testing for speculative bubbles in agricultural commodity prices: A regime switching approach. Agricultural Finance Review, 73(1):179200.

Masters, M. (2008). Testimony before the committee on homeland security and government affairs, US Senate. Internet Site: http://hsgac. senate. gov/public/_files/052008Masters.pdf (Accessed May 20, 2008).

Miffre, J. and Brooks, C. (2013). Do long-short speculators destabilize commodity futures markets? International Review of Financial Analysis, 30:230-240.

O'Hara, M. (2008). Bubbles: Some perspectives (and loose talk) from history. Review of Financial Studies, 21(1):11-17.

Phillips, P. C. and Yu, J. (2011). Dating the timeline of financial bubbles during the subprime crisis. Quantitative Economics, 2(3):455-491.

Pindyck, R. S. (1993). The present value model of rational commodity pricing. NBER Working paper $w 4083$.

Robles, M., Torero, M., and Von Braun, J. (2009). When speculation matters. International Food Policy Research Institute Washington, DC.

Roche, M. J. (2001). The rise in house prices in dublin: bubble, fad or just fundamentals. Economic Modelling, 18(2):281-295. 
Sanders, D., Irwin, S., and Merrin, R. (2010). The adequacy of speculation in agricultural futures markets: too much of a good thing? Applied Economic Perspectives, 32:77-94.

Sanders, D. R. and Irwin, S. H. (2010). A speculative bubble in commodity futures prices? Cross-sectional evidence. Agricultural Economics, 41(1):25-32.

Sanders, D. R. and Irwin, S. H. (2011). The impact of index funds in commodity futures markets: A systems approach. Journal of Alternative Investments, 14(1):40-49.

Schaller, H. and van Norden, S. (2002). Fads or bubbles? Empirical Economics, 27(2):335362.

Shi, S. and Arora, V. (2012). An application of models of speculative behaviour to oil prices. Economics Letters, 115(3):469-472.

Singleton, K. (2014). Investor flows and the 2008 boom/bust in oil prices. Management Science, 60:300-318.

Stoll, H. R. and Whaley, R. E. (2010). Commodity index investing and commodity futures prices. Journal of Applied Finance, 20(1):7-46.

Stoll, H. R. and Whaley, R. E. (2011). Commodity index investing: Speculation or diversification? Journal of Alternative Investments, 14(1):50-60.

Tang, K. and Xiong, W. (2012). Index investment and financialization of commodities. Financial Analyst Journal, 68(6):54-74.

van Norden, S. and Schaller, H. (1993). The predictability of stock market regime: Evidence from the toronto stock exchange. Review of Economics and Statistics, 75(3):505-10. 
Figure 1: Deviations From Fundamentals and the Real Price

In these plots, Real price refers to the deflated most nearby futures price, and Fundamental Value $\left(P_{t}^{*} 1\right)$ is computed based on convenience yields and ( $\left.P_{t}^{*} 2\right)$ is based on macroeconomic variables. All the time series are employed on a monthly basis.

oats
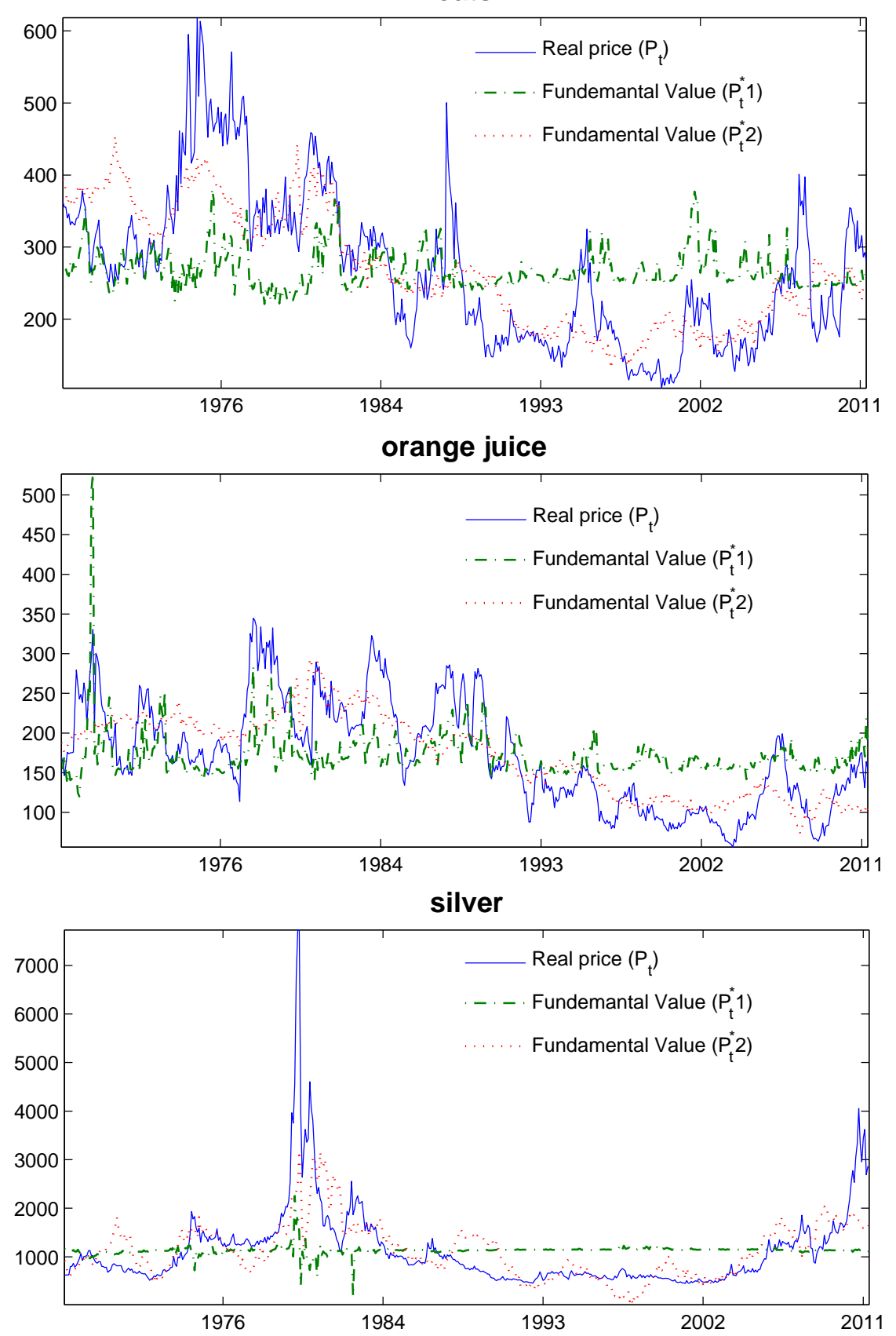

corn
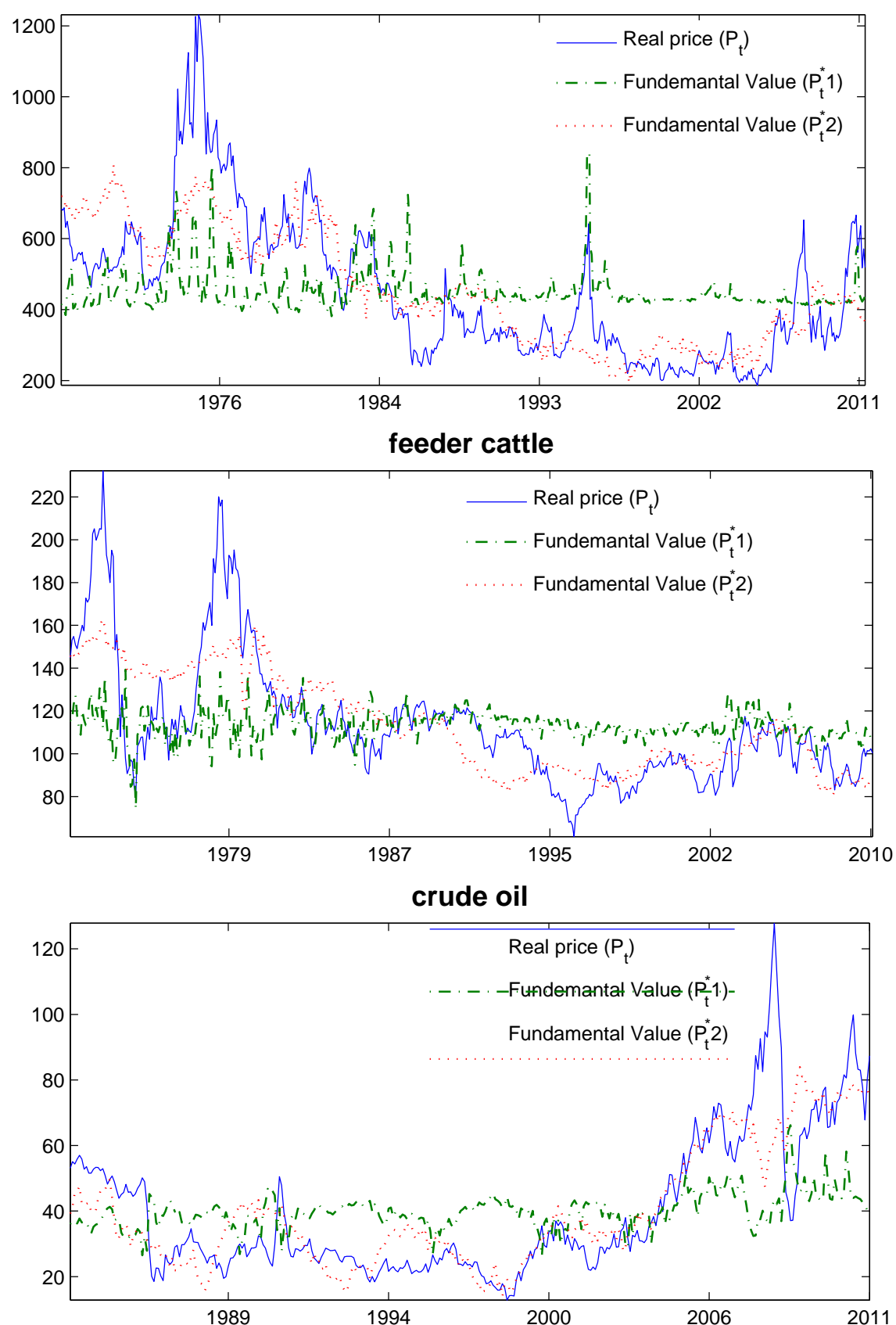
Figure 2: Probability of Collapse versus the Spot Price of Feeder Cattle and Crude Oil

In these plots, Real spot price refers to the deflated most nearby futures price, and the Probability of collapse is the ex ante probability based on the convenience yield approach.
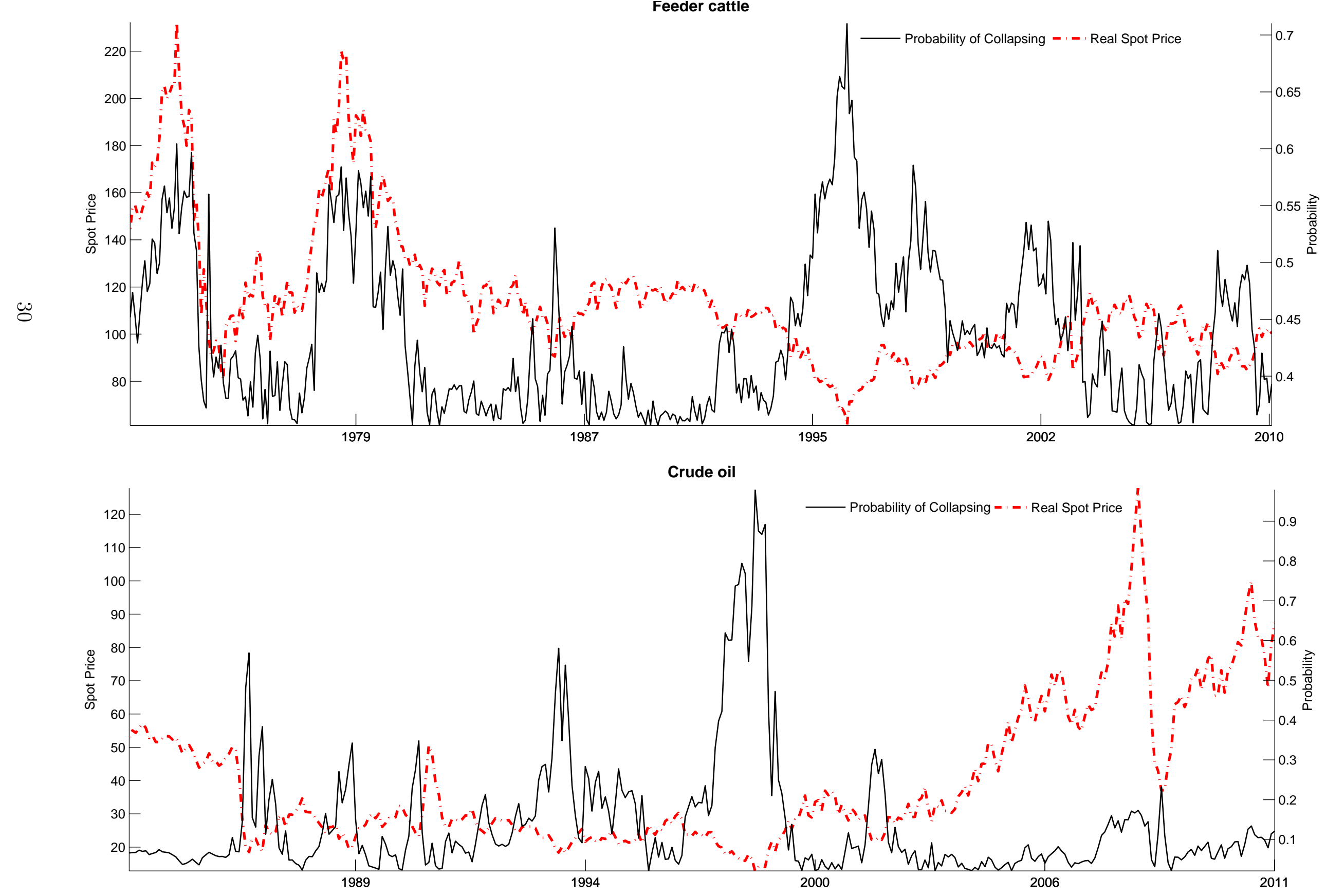
Figure 3: Probability of Collapse versus the Spot Price of Feeder Cattle and Crude Oil

In these plots, Real spot price refers to the deflated most nearby futures price, and the Probability of collapse is the ex ante probability based on fundamentals estimated using macroeconomic variables.
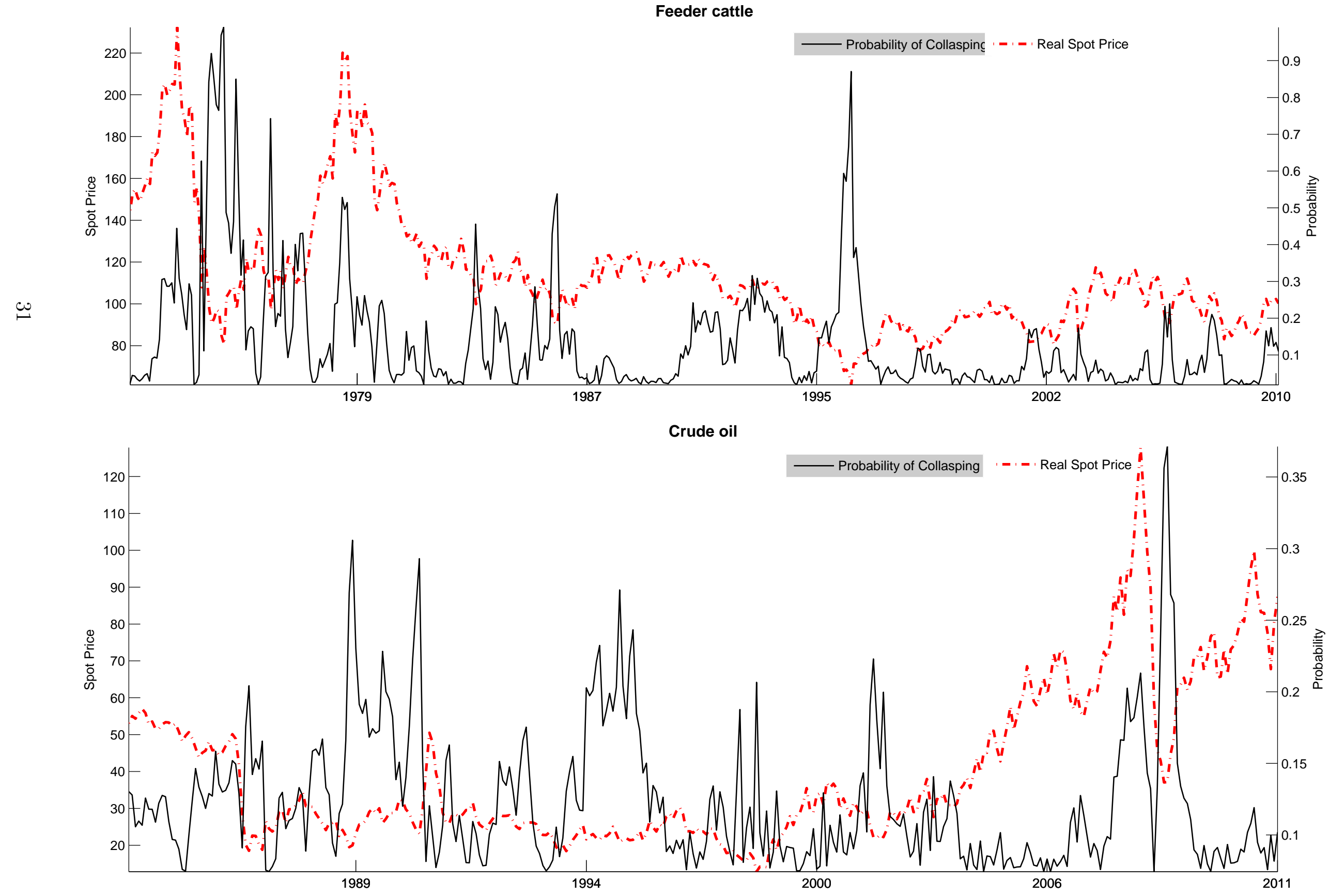
Table 1: Commodity Data

Panel $A$ of the table lists the exchanges where commodities are traded, the start dates, end dates and number of observations for each commodity used in this study. Panels $B$ and $C$ present descriptive statistics of the most nearby futures prices and excess returns, in real terms, respectively.

\begin{tabular}{|c|c|c|c|c|c|c|c|c|c|c|c|c|c|}
\hline \multirow[b]{2}{*}{ Sector } & \multirow[b]{2}{*}{ Commodity } & \multicolumn{4}{|c|}{ Panel A: Commodity Contracts } & \multicolumn{4}{|c|}{ Panel B: Most Nearby Futures Prices } & \multicolumn{4}{|c|}{ Panel C: Excess Returns } \\
\hline & & Exchange & Start date & End date & Obs. & Mean & S.D. & Skew. & Kurt. & Mean & S.D. & Skew. & Kurt. \\
\hline \multirow{6}{*}{ Grains } & Oats & $\mathrm{CBT}$ & $2 / 1 / 1967$ & $12 / 30 / 2011$ & 539 & 268.40 & 105.34 & 0.71 & 3.07 & -0.07 & 1.15 & 0.72 & 6.27 \\
\hline & Wheat & $\mathrm{CBT}$ & $2 / 1 / 1967$ & $12 / 30 / 2011$ & 545 & 605.73 & 280.35 & 1.84 & 7.97 & -0.12 & 0.97 & 0.34 & 4.79 \\
\hline & Corn & $\mathrm{CBT}$ & $2 / 1 / 1967$ & $12 / 30 / 2011$ & 539 & 453.66 & 202.04 & 1.08 & 4.14 & -0.14 & 0.94 & 1.07 & 11.31 \\
\hline & Soybeans & CBT & $2 / 1 / 1967$ & $12 / 30 / 2011$ & 539 & 1094.56 & 499.18 & 1.80 & 8.50 & -0.01 & 0.99 & 0.74 & 8.30 \\
\hline & Soybean oil & $\mathrm{CBT}$ & $2 / 1 / 1967$ & $12 / 30 / 2011$ & 539 & 39.74 & 19.22 & 2.08 & 9.73 & 0.04 & 1.16 & 0.96 & 6.69 \\
\hline & Soybean meal & $\mathrm{CBT}$ & $2 / 1 / 1967$ & $12 / 30 / 2011$ & 539 & 312.41 & 138.56 & 2.87 & 18.44 & 0.06 & 1.18 & 0.60 & 7.92 \\
\hline \multirow{4}{*}{ Soft } & Orange juice & ICE & $2 / 1 / 1967$ & $12 / 30 / 2011$ & 539 & 172.17 & 66.48 & 0.38 & 2.31 & -0.01 & 1.17 & 1.15 & 8.58 \\
\hline & Cotton & ICE & $2 / 1 / 1967$ & $12 / 30 / 2011$ & 539 & 107.76 & 48.27 & 1.09 & 4.87 & -0.09 & 0.99 & 0.13 & 4.58 \\
\hline & Coffee & $\mathrm{ICE}$ & $11 / 3 / 1975$ & $12 / 30 / 2011$ & 434 & 195.00 & 132.52 & 1.90 & 7.73 & -0.02 & 1.36 & 0.30 & 4.36 \\
\hline & Cocoa & $\mathrm{ICE}$ & $2 / 1 / 1967$ & $12 / 30 / 2011$ & 539 & 3015.13 & 2141.63 & 2.06 & 7.53 & -0.04 & 1.14 & 0.42 & 3.83 \\
\hline \multirow{2}{*}{ Wood\&Animal } & Feeder cattle & $\mathrm{CME}$ & $1 / 3 / 1972$ & $10 / 28 / 2010$ & 466 & 113.31 & 29.40 & 1.55 & 5.49 & 0.03 & 0.65 & -0.47 & 6.08 \\
\hline & Lumber & $\mathrm{CME}$ & $10 / 1 / 1969$ & $11 / 15 / 2010$ & 494 & 349.77 & 108.76 & 0.64 & 2.80 & -0.24 & 1.27 & 0.11 & 4.10 \\
\hline \multirow{3}{*}{ Precious metal } & Silver & Comex & $2 / 1 / 1967$ & $12 / 30 / 2011$ & 539 & 1129.32 & 833.64 & 3.57 & 22.43 & -0.07 & 1.18 & -1.63 & 21.69 \\
\hline & Gold & Comex & $1 / 2 / 1975$ & $12 / 30 / 2011$ & 444 & 589.18 & 260.77 & 1.57 & 5.35 & -0.05 & 0.66 & -0.03 & 6.52 \\
\hline & Platinum & NYMEX & $11 / 2 / 1970$ & $12 / 30 / 2011$ & 494 & 737.72 & 335.29 & 1.46 & 4.76 & -0.01 & 1.08 & 0.28 & 13.12 \\
\hline \multirow{3}{*}{ Energy } & Crude oil & NYMEX & $4 / 4 / 1983$ & $12 / 30 / 2011$ & 345 & 39.97 & 21.22 & 1.30 & 4.26 & 0.07 & 1.33 & -0.51 & 4.91 \\
\hline & Heating oil & NYMEX & $12 / 1 / 1978$ & $12 / 30 / 2011$ & 397 & 1.19 & 0.61 & 0.99 & 3.45 & 0.06 & 1.33 & 0.71 & 7.82 \\
\hline & Natural gas & NYMEX & 4/4/1990 & $12 / 30 / 2011$ & 261 & 4.21 & 2.30 & 1.40 & 5.00 & -0.42 & 2.27 & 0.11 & 5.54 \\
\hline
\end{tabular}


Table 2: Descriptive Statistics of Bubble Terms

This table displays descriptive statistics of the bubble terms. Panel A shows the relative bubble terms $b_{t}(1)$ estimated using convenience yields while Panel $B$ shows those of $b_{t}(2)$ based on fundamentals estimated using macroeconomic variables. The columns headings Min., Max., S.D., Skew., Kurt. stand for minimum, maximum, standard deviation, skewness and kurtosis, respectively.

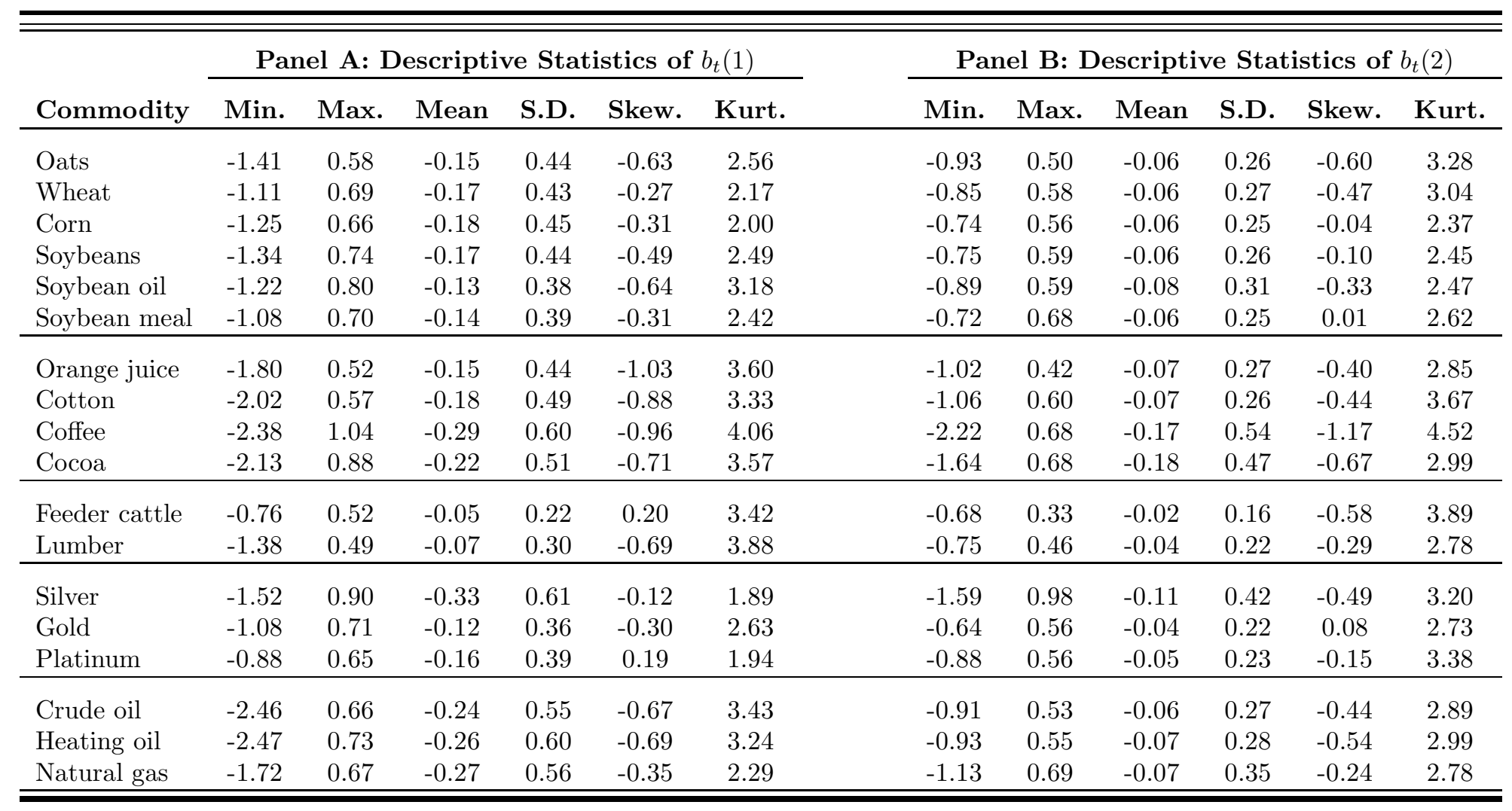


Table 3: Switching Regression Results Based on Convenience Yield

This table displays the results of the switching regression in Equation (17). The coefficients are presented together with the standard errors (in parentheses). Estimates significant at the 10\%, 5\% and 1\% levels are marked with *, **, *** respectively. The column headed 'LL' shows the negative of the log-likelihood value.

\begin{tabular}{|c|c|c|c|c|c|c|c|c|c|}
\hline Commodity & $\beta_{S, 0}$ & $\beta_{S, 1}$ & $\beta_{C, 0}$ & $\beta_{C, 1}$ & $\beta_{q, 0}$ & $\beta_{q, 1}$ & $\sigma_{S}$ & $\sigma_{C}$ & LL \\
\hline Oats & $\begin{array}{l}-0.13 \\
(0.55)\end{array}$ & $\begin{array}{l}0.12 \\
(0.13)\end{array}$ & $\begin{array}{l}0.13 \\
(0.27)\end{array}$ & $\begin{array}{l}-2.09^{* * *} \\
(0.80)\end{array}$ & $\begin{array}{l}0.81^{* * *} \\
(0.2)\end{array}$ & $\begin{array}{l}0.33 \\
(0.36)\end{array}$ & $\begin{array}{l}0.89^{* * *} \\
(0.21)\end{array}$ & $\begin{array}{l}1.72^{* * *} \\
(0.44)\end{array}$ & 813.57 \\
\hline Wheat & $\begin{array}{l}-0.19 \\
(0.13)\end{array}$ & $\begin{array}{l}-0.16 \\
(0.18)\end{array}$ & $\begin{array}{l}0.28^{* *} \\
(0.13)\end{array}$ & $\begin{array}{l}-0.42^{* *} \\
(0.19)\end{array}$ & $\begin{array}{l}0.99^{* * *} \\
(0.09)\end{array}$ & $\begin{array}{l}0.72^{* * *} \\
(0.15)\end{array}$ & $\begin{array}{l}0.81^{* * *} \\
(0.08)\end{array}$ & $\begin{array}{l}1.73^{* * *} \\
(0.27)\end{array}$ & 730.34 \\
\hline Corn & $\begin{array}{l}-0.15 \\
(0.29)\end{array}$ & $\begin{array}{l}0.03 \\
(0.40)\end{array}$ & $\begin{array}{l}-0.11 \\
(0.83)\end{array}$ & $\begin{array}{l}-0.19 \\
(0.47)\end{array}$ & $\begin{array}{l}0.68 \\
(0.49)\end{array}$ & $\begin{array}{l}0.56 \\
(0.35)\end{array}$ & $\begin{array}{l}0.64^{* *} \\
(0.32)\end{array}$ & $\begin{array}{l}1.73^{* * *} \\
(0.28)\end{array}$ & 686.96 \\
\hline Soybeans & $\begin{array}{l}-0.11^{*} \\
(0.06)\end{array}$ & $\begin{array}{l}-0.16 \\
(0.17)\end{array}$ & $\begin{array}{l}0.12 \\
(0.26)\end{array}$ & $\begin{array}{l}-0.11 \\
(0.47)\end{array}$ & $\begin{array}{l}0.71^{* * *} \\
(0.18)\end{array}$ & $\begin{array}{l}-0.59 \\
(0.92)\end{array}$ & $\begin{array}{l}0.53^{* * *} \\
(0.08)\end{array}$ & $\begin{array}{l}1.56^{* * *} \\
(0.20)\end{array}$ & 697.16 \\
\hline Soybean oil & $\begin{array}{l}-0.17 \\
(0.17)\end{array}$ & $\begin{array}{l}-0.22 \\
(0.30)\end{array}$ & $\begin{array}{l}0.63 \\
(0.62)\end{array}$ & $\begin{array}{l}-0.07 \\
(0.52)\end{array}$ & $\begin{array}{l}0.63 \\
(0.53)\end{array}$ & $\begin{array}{l}0.34 \\
(1.46)\end{array}$ & $\begin{array}{l}0.74^{* * *} \\
(0.11)\end{array}$ & $\begin{array}{l}1.87^{* * *} \\
(0.49)\end{array}$ & 792.73 \\
\hline Soybean meal & $\begin{array}{l}-0.11^{* *} \\
(0.05)\end{array}$ & $\begin{array}{l}-0.36^{* * *} \\
(0.09)\end{array}$ & $\begin{array}{l}0.44^{*} \\
(0.26)\end{array}$ & $\begin{array}{l}-0.67^{* * *} \\
(0.25)\end{array}$ & $\begin{array}{l}0.84^{* * *} \\
(0.19)\end{array}$ & $\begin{array}{l}-0.10 \\
(0.31) \\
\end{array}$ & $\begin{array}{l}0.75^{* * *} \\
(0.06)\end{array}$ & $\begin{array}{l}2.03^{* * *} \\
(0.22)\end{array}$ & 798.20 \\
\hline Orange juice & $\begin{array}{l}-0.12 \\
(0.26)\end{array}$ & $\begin{array}{l}-0.04 \\
(0.29)\end{array}$ & $\begin{array}{l}1.03 \\
(1.07)\end{array}$ & $\begin{array}{l}0.32 \\
(1.62)\end{array}$ & $\begin{array}{l}1.26^{* * *} \\
(0.29)\end{array}$ & $\begin{array}{l}0.12 \\
(0.69)\end{array}$ & $\begin{array}{l}0.90^{* * *} \\
(0.12)\end{array}$ & $\begin{array}{l}2.36^{* * *} \\
(0.48)\end{array}$ & 804.49 \\
\hline Cotton & $\begin{array}{l}-0.13 \\
(0.23)\end{array}$ & $\begin{array}{l}-0.10 \\
(0.26)\end{array}$ & $\begin{array}{l}-0.03 \\
(0.10)\end{array}$ & $\begin{array}{l}0.09 \\
(0.88)\end{array}$ & $\begin{array}{l}0.54 \\
(2.11)\end{array}$ & $\begin{array}{l}-1.72 \\
(2.97)\end{array}$ & $\begin{array}{l}0.52 \\
(0.40)\end{array}$ & $\begin{array}{l}1.26^{* * *} \\
(0.20)\end{array}$ & 729.79 \\
\hline Coffee & $\begin{array}{l}-0.16 \\
(0.14)\end{array}$ & $\begin{array}{l}0.27 \\
(0.17)\end{array}$ & $\begin{array}{l}0.18^{* *} \\
(0.07)\end{array}$ & $\begin{array}{l}-0.35^{* * *} \\
(0.08)\end{array}$ & $\begin{array}{l}0.02 \\
(0.19)\end{array}$ & $\begin{array}{l}0.25^{*} \\
(0.13)\end{array}$ & $\begin{array}{l}0.85 * * * \\
(0.06)\end{array}$ & $\begin{array}{l}1.74^{* * *} \\
(0.14)\end{array}$ & 733.86 \\
\hline Cocoa & $\begin{array}{l}-0.14 \\
(0.15) \\
\end{array}$ & $\begin{array}{l}-0.11 \\
(0.12) \\
\end{array}$ & $\begin{array}{l}0.22 \\
(0.19) \\
\end{array}$ & $\begin{array}{l}0.44 \\
(0.58) \\
\end{array}$ & $\begin{array}{l}-0.36 \\
(0.54) \\
\end{array}$ & $\begin{array}{l}4.04^{* * *} \\
(0.81) \\
\end{array}$ & $\begin{array}{l}1.00^{* * *} \\
(0.25) \\
\end{array}$ & $\begin{array}{l}1.52^{* * *} \\
(0.33)\end{array}$ & 824.79 \\
\hline Feeder cattle & $\begin{array}{l}0.14 \\
(0.10)\end{array}$ & $\begin{array}{l}0.44^{*} \\
(0.27)\end{array}$ & $\begin{array}{l}-0.10 \\
(0.08)\end{array}$ & $\begin{array}{l}-0.78^{* *} \\
(0.32)\end{array}$ & $\begin{array}{l}0.37 \\
(0.23)\end{array}$ & $\begin{array}{l}-1.22^{* *} \\
(0.51)\end{array}$ & $\begin{array}{l}0.36 * * * \\
(0.04)\end{array}$ & $\begin{array}{l}0.87^{* * *} \\
(0.07)\end{array}$ & 430.93 \\
\hline Lumber & $\begin{array}{l}-0.26^{* * *} \\
(0.09)\end{array}$ & $\begin{array}{l}0.13 \\
(0.18) \\
\end{array}$ & $\begin{array}{l}2.79 * * * \\
(0.26) \\
\end{array}$ & $\begin{array}{l}138.63^{* * *} \\
(10.10)\end{array}$ & $\begin{array}{l}1.10^{* * *} \\
(0.19)\end{array}$ & $\begin{array}{l}34.38^{*} \\
(20.14) \\
\end{array}$ & $\begin{array}{l}1.23^{* * *} \\
(0.09)\end{array}$ & $\begin{array}{l}0.25^{* *} \\
(0.10)\end{array}$ & 807.62 \\
\hline Silver & $\begin{array}{l}-0.12 \\
(0.09)\end{array}$ & $\begin{array}{l}-0.10 \\
(0.14)\end{array}$ & $\begin{array}{l}-0.04 \\
(0.27)\end{array}$ & $\begin{array}{c}-0.68^{*} \\
(0.35)\end{array}$ & $\begin{array}{l}0.53^{* * *} \\
(0.13)\end{array}$ & $\begin{array}{l}0.71^{*} \\
(0.37)\end{array}$ & $\begin{array}{l}0.71^{* * *} \\
(0.04)\end{array}$ & $\begin{array}{l}2.27^{* * *} \\
(0.31)\end{array}$ & 776.56 \\
\hline Gold & $\begin{array}{l}-0.06 \\
(0.06)\end{array}$ & $\begin{array}{l}-0.04 \\
(0.15)\end{array}$ & $\begin{array}{l}-0.06 \\
(0.34)\end{array}$ & $\begin{array}{l}-0.63 \\
(0.63)\end{array}$ & $\begin{array}{l}0.67^{*} \\
(0.41)\end{array}$ & $\begin{array}{l}1.17^{* * *} \\
(0.21)\end{array}$ & $\begin{array}{l}0.48^{* * *} \\
(0.15)\end{array}$ & $\begin{array}{l}1.21^{* * *} \\
(0.11)\end{array}$ & 413.79 \\
\hline Platinum & $\begin{array}{l}-0.02 \\
(0.20) \\
\end{array}$ & $\begin{array}{l}-0.07 \\
(0.26) \\
\end{array}$ & $\begin{array}{l}0.00 \\
(0.23) \\
\end{array}$ & $\begin{array}{l}-2.08^{* *} \\
(0.97) \\
\end{array}$ & $\begin{array}{l}0.74^{* *} \\
(0.36) \\
\end{array}$ & $\begin{array}{l}1.27^{* * *} \\
(0.41)\end{array}$ & $\begin{array}{l}0.70 * * \\
(0.29) \\
\end{array}$ & $\begin{array}{l}2.32^{* * *} \\
(0.54)\end{array}$ & 658.80 \\
\hline Crude oil & $\begin{array}{l}0.18 \\
(0.79)\end{array}$ & $\begin{array}{l}-0.13 \\
(0.26)\end{array}$ & $\begin{array}{l}-1.48^{* * *} \\
(0.27)\end{array}$ & $\begin{array}{l}-0.99 * * \\
(0.46)\end{array}$ & $\begin{array}{l}2.04^{* * *} \\
(0.59)\end{array}$ & $\begin{array}{l}-1.66 \\
(2.86)\end{array}$ & $\begin{array}{l}1.08^{*} \\
(0.58)\end{array}$ & $\begin{array}{l}2.04^{* * *} \\
(0.74)\end{array}$ & 569.17 \\
\hline Heating oil & $\begin{array}{l}0.03 \\
(0.33)\end{array}$ & $\begin{array}{l}-0.06 \\
(0.24)\end{array}$ & $\begin{array}{l}-0.02 \\
(0.20)\end{array}$ & $\begin{array}{l}-0.45 \\
(0.34)\end{array}$ & $\begin{array}{l}1.03^{* * *} \\
(0.23)\end{array}$ & $\begin{array}{l}-0.32 \\
(0.34)\end{array}$ & $\begin{array}{l}0.91^{* * *} \\
(0.19)\end{array}$ & $\begin{array}{l}2.35^{* * *} \\
(0.63)\end{array}$ & 644.44 \\
\hline Natural gas & $\begin{array}{l}1.94^{*} \\
(1.00)\end{array}$ & $\begin{array}{l}-7.4^{* * *} \\
(1.00)\end{array}$ & $\begin{array}{l}-0.54^{* * *} \\
(0.14)\end{array}$ & $\begin{array}{c}-0.45^{*} \\
(0.26)\end{array}$ & $\begin{array}{l}-93.08^{* * *} \\
(0.98)\end{array}$ & $\begin{array}{l}-46.58^{* * *} \\
(0.99)\end{array}$ & $\begin{array}{l}266.14^{* * *} \\
(0.77)\end{array}$ & $\begin{array}{l}2.26^{* * *} \\
(0.09)\end{array}$ & 580.42 \\
\hline
\end{tabular}


Table 4: Likelihood Ratio Tests from Switching Regression Results Based on Convenience Yield

This table displays the likelihood ratio test statistics of the switching regression in Equation (17) with pvalues in square brackets. The statistics significant at the 10\%, 5\% and 1\% levels are marked with *, **, *** respectively.

\begin{tabular}{|c|c|c|c|c|}
\hline Commodity & $\beta_{S 0} \neq \beta_{C 0}$ & $\beta_{C 1}<0$ & $\beta_{S 1}>\beta_{C 1}$ & $\beta_{q 1}<0$ \\
\hline \multirow[t]{2}{*}{ Oats } & 0.77 & $5.04^{* *}$ & $4.93^{* *}$ & 0.50 \\
\hline & {$[0.38]$} & {$[0.02]$} & {$[0.03]$} & {$[0.48]$} \\
\hline \multirow[t]{2}{*}{ Wheat } & 1.96 & 0.22 & 0.08 & 1.50 \\
\hline & {$[0.16]$} & {$[0.64]$} & {$[0.78]$} & {$[0.22]$} \\
\hline \multirow[t]{2}{*}{ Corn } & 0.02 & 0.14 & 0.18 & 1.64 \\
\hline & {$[0.87]$} & {$[0.71]$} & {$[0.67]$} & {$[0.20]$} \\
\hline \multirow[t]{2}{*}{ Soybeans } & 2.25 & 0.15 & 0.03 & 2.39 \\
\hline & {$[0.13]$} & {$[0.70]$} & {$[0.86]$} & {$[0.12]$} \\
\hline \multirow[t]{2}{*}{ Soybean oil } & $12.15^{* * *}$ & 0.01 & 0.05 & 0.55 \\
\hline & {$[0.00]$} & {$[0.91]$} & {$[0.82]$} & {$[0.46]$} \\
\hline \multirow[t]{2}{*}{ Soybean meal } & $4.34^{* *}$ & 1.50 & 0.26 & 0.05 \\
\hline & {$[0.04]$} & {$[0.22]$} & {$[0.61]$} & {$[0.82]$} \\
\hline \multirow[t]{2}{*}{ Orange juice } & $6.77^{* * *}$ & 0.10 & 0.12 & 0.04 \\
\hline & {$[0.01]$} & {$[0.75]$} & {$[0.73]$} & {$[0.85]$} \\
\hline \multirow[t]{2}{*}{ Cotton } & 0.41 & 0.43 & 0.45 & $14.66^{* * *}$ \\
\hline & {$[0.52]$} & {$[0.51]$} & {$[0.50]$} & {$[0.00]$} \\
\hline \multirow[t]{2}{*}{ Coffee } & 2.12 & 1.51 & $3.26^{*}$ & 0.67 \\
\hline & {$[0.15]$} & {$[0.22]$} & {$[0.07]$} & {$[0.41]$} \\
\hline \multirow[t]{2}{*}{ Cocoa } & 2.11 & 0.17 & 0.27 & -11.12 \\
\hline & {$[0.15]$} & {$[0.68]$} & {$[0.61]$} & {$[1.00]$} \\
\hline \multirow[t]{2}{*}{ Feeder cattle } & $4.84^{* *}$ & $6.93^{* * *}$ & $6.90^{* * *}$ & 2.32 \\
\hline & {$[0.03]$} & {$[0.01]$} & {$[0.01]$} & {$[0.13]$} \\
\hline \multirow[t]{2}{*}{ Lumber } & $8.51^{* * *}$ & $12.89^{* * *}$ & $12.89^{* * *}$ & $22.22^{* * *}$ \\
\hline & {$[0.00]$} & {$[0.00]$} & {$[0.00]$} & {$[0.00]$} \\
\hline \multirow[t]{2}{*}{ Silver } & 0.09 & 1.98 & 1.33 & $6.17^{* *}$ \\
\hline & {$[0.77]$} & {$[0.16]$} & {$[0.25]$} & {$[0.01]$} \\
\hline \multirow[t]{2}{*}{ Gold } & 0.00 & 1.00 & 0.77 & $3.23^{*}$ \\
\hline & {$[0.97]$} & {$[0.32]$} & {$[0.38]$} & {$[0.07]$} \\
\hline \multirow[t]{2}{*}{ Platinum } & 0.00 & $4.41^{* *}$ & $3.99^{* *}$ & $5.18^{* *}$ \\
\hline & {$[0.95]$} & {$[0.04]$} & {$[0.05]$} & {$[0.02]$} \\
\hline \multirow[t]{2}{*}{ Crude oil } & $4.60 * *$ & 2.57 & 1.75 & $5.76^{* *}$ \\
\hline & {$[0.03]$} & {$[0.11]$} & {$[0.19]$} & {$[0.02]$} \\
\hline \multirow[t]{2}{*}{ Heating oil } & 0.02 & 0.93 & 0.54 & 0.91 \\
\hline & {$[0.89]$} & {$[0.33]$} & {$[0.46]$} & {$[0.34]$} \\
\hline \multirow[t]{2}{*}{ Natural gas } & 0.00 & $3.29 *$ & 0.00 & 0.00 \\
\hline & {$[1.00]$} & {$[0.07]$} & {$[1.00]$} & {$[1.00]$} \\
\hline
\end{tabular}


Table 5: Switching Regression Results Based on Macroeconomic Variables

This table displays the results of the switching regression in Equation (17). The coefficients are presented together with the standard errors (in parentheses). Estimates significant at the 10\%, 5\% and 1\% levels are marked with *, **, *** respectively. The column headed 'LL' shows the negative of the log-likelihood value.

\begin{tabular}{|c|c|c|c|c|c|c|c|c|c|}
\hline Commodity & $\beta_{S, 0}$ & $\beta_{S, 1}$ & $\beta_{C, 0}$ & $\beta_{C, 1}$ & $\beta_{q, 0}$ & $\beta_{q, 1}$ & $\sigma_{S}$ & $\sigma_{C}$ & LL \\
\hline Oats & $\begin{array}{l}-0.17 \\
(0.13)\end{array}$ & $\begin{array}{l}-0.15 \\
(0.18)\end{array}$ & $\begin{array}{l}1.74^{* * *} \\
(0.36)\end{array}$ & $\begin{array}{l}1.69^{* * *} \\
(0.54)\end{array}$ & $\begin{array}{l}1.52^{* * *} \\
(0.42)\end{array}$ & $\begin{array}{l}0.56^{* * *} \\
(0.21)\end{array}$ & $\begin{array}{l}1.00^{* * *} \\
(0.07)\end{array}$ & $\begin{array}{l}1.95^{* * *} \\
(0.32)\end{array}$ & 816.94 \\
\hline Wheat & $\begin{array}{l}0.96^{* * *} \\
(0.07)\end{array}$ & $\begin{array}{l}2.60^{* * *} \\
(0.35)\end{array}$ & $\begin{array}{l}-0.29^{* * *} \\
(0.04)\end{array}$ & $\begin{array}{l}-0.44^{* * *} \\
(0.10)\end{array}$ & $\begin{array}{l}-1.04^{* * *} \\
(0.10)\end{array}$ & $\begin{array}{l}-0.55^{* * *} \\
(0.10)\end{array}$ & $\begin{array}{l}1.03^{* * *} \\
(0.05)\end{array}$ & $\begin{array}{l}0.83^{* * *} \\
(0.03)\end{array}$ & 728.57 \\
\hline Corn & $\begin{array}{l}-0.15^{*} \\
(0.08)\end{array}$ & $\begin{array}{l}0.06 \\
(0.16)\end{array}$ & $\begin{array}{l}-0.11 \\
(0.24)\end{array}$ & $\begin{array}{l}-0.32^{* *} \\
(0.14)\end{array}$ & $\begin{array}{l}1.09^{* * *} \\
(0.21)\end{array}$ & $\begin{array}{l}-1.13^{* * *} \\
(0.06)\end{array}$ & $\begin{array}{l}0.63^{* * *} \\
(0.03)\end{array}$ & $\begin{array}{l}1.69^{* * *} \\
(0.15)\end{array}$ & 686.75 \\
\hline Soybeans & $\begin{array}{l}-0.10^{* * *} \\
(0.04)\end{array}$ & $\begin{array}{l}-0.15 \\
(0.23)\end{array}$ & $\begin{array}{l}0.16 \\
(0.16)\end{array}$ & $\begin{array}{l}-0.61 \\
(1.05)\end{array}$ & $\begin{array}{l}0.57 \\
(0.60)\end{array}$ & $\begin{array}{l}-0.16 \\
(0.29)\end{array}$ & $\begin{array}{l}0.54^{* * *} \\
(0.07)\end{array}$ & $\begin{array}{l}1.58^{* * *} \\
(0.33)\end{array}$ & 698.80 \\
\hline Soybean oil & $\begin{array}{l}-0.13^{* * *} \\
(0.03)\end{array}$ & $\begin{array}{l}0.00 \\
(0.08)\end{array}$ & $\begin{array}{l}0.52^{* * *} \\
(0.08)\end{array}$ & $\begin{array}{l}-0.65^{* * * *} \\
(0.09)\end{array}$ & $\begin{array}{l}0.75^{* * *} \\
(0.07)\end{array}$ & $\begin{array}{l}-0.34^{* * *} \\
(0.07)\end{array}$ & $\begin{array}{l}0.71^{* * *} \\
(0.03)\end{array}$ & $\begin{array}{l}1.84^{* * *} \\
(0.10)\end{array}$ & 793.41 \\
\hline Soybean meal & $\begin{array}{l}-0.12^{* * *} \\
(0.04)\end{array}$ & $\begin{array}{l}-0.55^{* * *} \\
(0.15)\end{array}$ & $\begin{array}{l}0.44 \\
(0.59) \\
\end{array}$ & $\begin{array}{l}-0.46 \\
(0.66)\end{array}$ & $\begin{array}{l}0.84^{* *} \\
(0.37)\end{array}$ & $\begin{array}{l}-0.96^{* * *} \\
(0.17)\end{array}$ & $\begin{array}{l}0.71^{*} \\
(0.37)\end{array}$ & $\begin{array}{l}1.90 \\
(1.91) \\
\end{array}$ & 799.72 \\
\hline Orange juice & $\begin{array}{l}-0.10^{* *} \\
(0.05)\end{array}$ & $\begin{array}{l}0.23 \\
(0.33)\end{array}$ & $\begin{array}{l}0.56 \\
(0.58)\end{array}$ & $\begin{array}{c}-0.67 \\
(0.49)\end{array}$ & $\begin{array}{l}1.38^{* * *} \\
(0.41)\end{array}$ & $\begin{array}{l}-1.36^{* * *} \\
(0.38)\end{array}$ & $\begin{array}{l}0.84^{* * *} \\
(0.08)\end{array}$ & $\begin{array}{l}2.16^{* * *} \\
(0.40)\end{array}$ & 802.26 \\
\hline Cotton & $\begin{array}{l}-0.14^{* * *} \\
(0.05)\end{array}$ & $\begin{array}{l}-0.08 \\
(0.12)\end{array}$ & $\begin{array}{l}-0.01 \\
(0.10)\end{array}$ & $\begin{array}{l}-0.19 \\
(0.35)\end{array}$ & $\begin{array}{l}0.91^{* * *} \\
(0.09)\end{array}$ & $\begin{array}{l}-1.89^{* * *} \\
(0.55)\end{array}$ & $\begin{array}{l}0.68 * * * \\
(0.05)\end{array}$ & $\begin{array}{l}1.44^{* * *} \\
(0.12)\end{array}$ & 734.11 \\
\hline Coffee & $\begin{array}{l}-0.19 \\
(0.19)\end{array}$ & $\begin{array}{l}0.18 \\
(0.24)\end{array}$ & $\begin{array}{l}0.24^{*} \\
(0.13)\end{array}$ & $\begin{array}{l}-0.14 \\
(0.18)\end{array}$ & $\begin{array}{l}0.20 \\
(0.29)\end{array}$ & $\begin{array}{l}0.04 \\
(0.26)\end{array}$ & $\begin{array}{l}0.90^{* * *} \\
(0.11)\end{array}$ & $\begin{array}{l}1.78^{* * *} \\
(0.13)\end{array}$ & 735.94 \\
\hline Cocoa & $\begin{array}{l}0.22^{*} \\
(0.12) \\
\end{array}$ & $\begin{array}{l}-0.16 \\
(0.23) \\
\end{array}$ & $\begin{array}{c}-0.43^{*} \\
(0.23) \\
\end{array}$ & $\begin{array}{l}-0.07 \\
(0.15) \\
\end{array}$ & $\begin{array}{l}0.32 \\
(0.41) \\
\end{array}$ & $\begin{array}{l}-0.40 \\
(0.45) \\
\end{array}$ & $\begin{array}{l}1.32^{* * *} \\
(0.08) \\
\end{array}$ & $\begin{array}{l}0.68^{* * *} \\
(0.10) \\
\end{array}$ & 819.09 \\
\hline Feeder cattle & $\begin{array}{l}0.05^{*} \\
(0.03)\end{array}$ & $\begin{array}{l}0.24 \\
(0.25)\end{array}$ & $\begin{array}{l}-0.19 \\
(0.36)\end{array}$ & $\begin{array}{l}-0.82 \\
(1.51)\end{array}$ & $\begin{array}{l}2.08^{*} \\
(1.24)\end{array}$ & $\begin{array}{l}-6.51^{* *} \\
(2.90)\end{array}$ & $\begin{array}{l}0.49 * * * \\
(0.08)\end{array}$ & $\begin{array}{l}1.24^{* *} \\
(0.60)\end{array}$ & 421.56 \\
\hline Lumber & $\begin{array}{l}0.05 \\
(0.11) \\
\end{array}$ & $\begin{array}{l}1.34^{* * *} \\
(0.44)\end{array}$ & $\begin{array}{l}-0.30^{* * *} \\
(0.10)\end{array}$ & $\begin{array}{l}-0.36 \\
(0.39) \\
\end{array}$ & $\begin{array}{l}-1.01^{* * *} \\
(0.30)\end{array}$ & $\begin{array}{l}0.52 \\
(0.99)\end{array}$ & $\begin{array}{l}0.41^{* * *} \\
(0.11)\end{array}$ & $\begin{array}{l}1.38^{* * *} \\
(0.16)\end{array}$ & 810.82 \\
\hline Silver & $\begin{array}{l}-0.04 \\
(0.07)\end{array}$ & $\begin{array}{l}0.18^{*} \\
(0.11)\end{array}$ & $\begin{array}{l}-0.10 \\
(0.39)\end{array}$ & $\begin{array}{l}-1.11^{* * * *} \\
(0.23)\end{array}$ & $\begin{array}{l}0.84^{* * *} \\
(0.24)\end{array}$ & $\begin{array}{l}0.23 \\
(0.25)\end{array}$ & $\begin{array}{l}0.72^{* * *} \\
(0.05)\end{array}$ & $\begin{array}{l}2.28^{* * *} \\
(0.30)\end{array}$ & 779.11 \\
\hline Gold & $\begin{array}{l}-0.06^{*} \\
(0.04)\end{array}$ & $\begin{array}{l}-0.12 \\
(0.50)\end{array}$ & $\begin{array}{l}-0.04 \\
(0.16)\end{array}$ & $\begin{array}{l}-0.18 \\
(0.16)\end{array}$ & $\begin{array}{l}1.14^{* * *} \\
(0.26)\end{array}$ & $\begin{array}{l}-1.97^{* * * *} \\
(0.68)\end{array}$ & $\begin{array}{l}0.45^{* * *} \\
(0.04)\end{array}$ & $\begin{array}{l}1.12^{* * *} \\
(0.15)\end{array}$ & 413.46 \\
\hline Platinum & $\begin{array}{l}-0.04 \\
(0.04) \\
\end{array}$ & $\begin{array}{l}-0.46^{* *} \\
(0.21)\end{array}$ & $\begin{array}{l}0.00 \\
(0.35) \\
\end{array}$ & $\begin{array}{l}-0.29 \\
(1.01) \\
\end{array}$ & $\begin{array}{l}1.37^{* * *} \\
(0.21)\end{array}$ & $\begin{array}{c}-1.67^{*} \\
(1.00)\end{array}$ & $\begin{array}{l}0.67^{* * *} \\
(0.05)\end{array}$ & $\begin{array}{l}2.24^{* * *} \\
(0.35)\end{array}$ & 659.32 \\
\hline Crude oil & $\begin{array}{l}0.13 \\
(0.09)\end{array}$ & $\begin{array}{l}-1.02^{* *} \\
(0.41)\end{array}$ & $\begin{array}{c}-0.92^{*} \\
(0.50)\end{array}$ & $\begin{array}{l}-1.36^{* * *} \\
(0.21)\end{array}$ & $\begin{array}{l}1.45^{* * *} \\
(0.54)\end{array}$ & $\begin{array}{l}-1.23^{* * * *} \\
(0.21)\end{array}$ & $\begin{array}{l}1.04^{* * *} \\
(0.06)\end{array}$ & $\begin{array}{l}2.27^{* * *} \\
(0.26)\end{array}$ & 563.88 \\
\hline Heating oil & $\begin{array}{l}-0.01 \\
(0.41)\end{array}$ & $\begin{array}{l}-0.75 \\
(1.26)\end{array}$ & $\begin{array}{l}0.05 \\
(2.56)\end{array}$ & $\begin{array}{l}-1.54 \\
(8.03)\end{array}$ & $\begin{array}{l}0.94^{* * *} \\
(0.06)\end{array}$ & $\begin{array}{l}-0.12 \\
(5.58)\end{array}$ & $\begin{array}{l}0.90^{* * *} \\
(0.27)\end{array}$ & $\begin{array}{l}2.38 \\
(4.07)\end{array}$ & 637.35 \\
\hline Natural gas & $\begin{array}{l}-13.14^{* * *} \\
(1.00)\end{array}$ & $\begin{array}{l}-16.00^{* * *} \\
(1.00)\end{array}$ & $\begin{array}{l}-0.43^{* *} \\
(0.17)\end{array}$ & $\begin{array}{l}-0.17 \\
(0.28) \\
\end{array}$ & $\begin{array}{l}-131.85^{* * *} \\
(0.98)\end{array}$ & $\begin{array}{l}-39.03^{* * *} \\
(1.00)\end{array}$ & $\begin{array}{l}400.34^{* * *} \\
(0.80)\end{array}$ & $\begin{array}{l}2.27^{* * *} \\
(0.28) \\
\end{array}$ & 581.98 \\
\hline
\end{tabular}


Table 6: Likelihood Ratio Tests from Switching Regression Results Based on Macroeconomic Variables

This table displays the likelihood ratio test statistics of the switching regression in Equation (17) with $p$ values in square brackets. The statistics significant at the 10\%, 5\% and 1\% levels are marked with *, **, *** respectively.

\begin{tabular}{|c|c|c|c|c|}
\hline Commodity & $\beta_{S 0} \neq \beta_{C 0}$ & $\beta_{C 1}<0$ & $\beta_{S 1}>\beta_{C 1}$ & $\beta_{q 1}<0$ \\
\hline \multirow[t]{2}{*}{ Oats } & $4.47^{* *}$ & 0.18 & 0.21 & 0.27 \\
\hline & {$[0.03]$} & {$[0.67]$} & {$[0.65]$} & {$[0.61]$} \\
\hline \multirow[t]{2}{*}{ Wheat } & $8.31^{* * *}$ & $5.87^{* *}$ & $6.90^{* * *}$ & 0.15 \\
\hline & {$[0.00]$} & {$[0.02]$} & {$[0.01]$} & {$[0.70]$} \\
\hline \multirow[t]{2}{*}{ Corn } & 0.03 & 0.24 & 0.26 & 2.19 \\
\hline & {$[0.85]$} & {$[0.62]$} & {$[0.61]$} & {$[0.14]$} \\
\hline \multirow[t]{2}{*}{ Soybeans } & $2.85^{*}$ & 1.51 & 0.68 & 0.06 \\
\hline & {$[0.09]$} & {$[0.22]$} & {$[0.41]$} & {$[0.80]$} \\
\hline \multirow[t]{2}{*}{ Soybean oil } & $9.56^{* * *}$ & 1.38 & 1.10 & 0.35 \\
\hline & {$[0.00]$} & {$[0.24]$} & {$[0.29]$} & {$[0.56]$} \\
\hline \multirow[t]{2}{*}{ Soybean meal } & $4.67^{* *}$ & 0.47 & 0.01 & 1.84 \\
\hline & {$[0.03]$} & {$[0.49]$} & {$[0.92]$} & {$[0.17]$} \\
\hline \multirow[t]{2}{*}{ Orange juice } & $3.82^{*}$ & 0.59 & 0.85 & $3.84^{* *}$ \\
\hline & {$[0.05]$} & {$[0.44]$} & {$[0.36]$} & {$[0.05]$} \\
\hline \multirow[t]{2}{*}{ Cotton } & 0.48 & 0.24 & 0.04 & $4.72^{* *}$ \\
\hline & {$[0.49]$} & {$[0.62]$} & {$[0.84]$} & {$[0.03]$} \\
\hline \multirow[t]{2}{*}{ Coffee } & $2.78^{*}$ & 0.19 & 0.53 & 0.01 \\
\hline & {$[0.10]$} & {$[0.66]$} & {$[0.47]$} & {$[0.91]$} \\
\hline \multirow[t]{2}{*}{ Cocoa } & $10.45^{* * *}$ & 0.22 & 0.07 & 0.90 \\
\hline & {$[0.00]$} & {$[0.64]$} & {$[0.79]$} & {$[0.34]$} \\
\hline \multirow[t]{2}{*}{ Feeder cattle } & 1.46 & 1.49 & 2.01 & $25.72^{* * *}$ \\
\hline & {$[0.23]$} & {$[0.22]$} & {$[0.16]$} & {$[0.00]$} \\
\hline \multirow[t]{2}{*}{ Lumber } & 2.22 & 1.08 & $3.35^{*}$ & 0.26 \\
\hline & {$[0.14]$} & {$[0.30]$} & {$[0.07]$} & {$[0.61]$} \\
\hline \multirow[t]{2}{*}{ Silver } & 0.05 & $2.80^{*}$ & $3.49^{*}$ & 0.37 \\
\hline & {$[0.83]$} & {$[0.09]$} & {$[0.06]$} & {$[0.54]$} \\
\hline \multirow[t]{2}{*}{ Gold } & 0.02 & 0.13 & 0.01 & $3.60^{*}$ \\
\hline & {$[0.89]$} & {$[0.72]$} & {$[0.91]$} & {$[0.06]$} \\
\hline \multirow[t]{2}{*}{ Platinum } & 0.01 & 0.09 & 0.03 & $2.97^{*}$ \\
\hline & {$[0.9]$} & {$[0.76]$} & {$[0.87]$} & {$[0.08]$} \\
\hline \multirow[t]{2}{*}{ Crude oil } & $3.23^{*}$ & 0.76 & 0.04 & -5.21 \\
\hline & {$[0.07]$} & {$[0.38]$} & {$[0.84]$} & {$[1.00]$} \\
\hline \multirow[t]{2}{*}{ Heating oil } & 0.02 & 1.68 & 0.36 & 0.01 \\
\hline & {$[0.88]$} & {$[0.19]$} & {$[0.55]$} & {$[0.91]$} \\
\hline \multirow[t]{2}{*}{ Natural gas } & 0.00 & 0.17 & 0.00 & 0.00 \\
\hline & {$[1.00]$} & {$[0.68]$} & {$[1.00]$} & {$[1.00]$} \\
\hline
\end{tabular}

